Biofuel Research Journal 14 (2017) 611-626

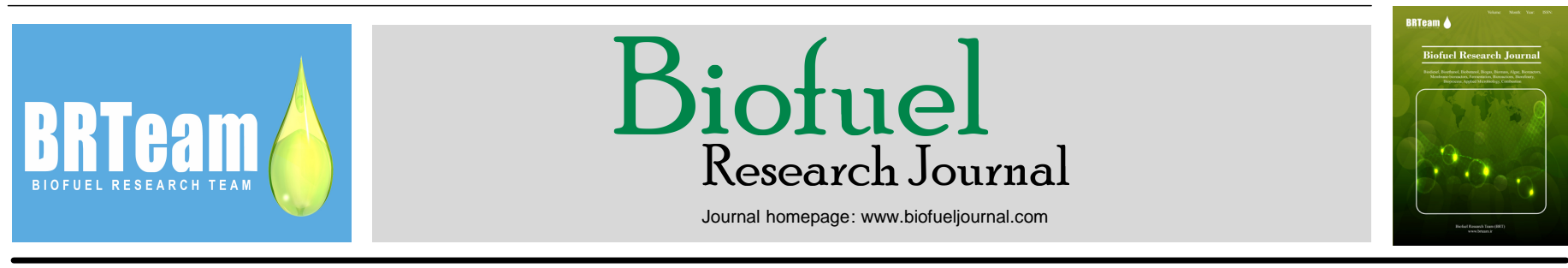

Review Paper

\title{
Applications of subcritical and supercritical water conditions for extraction, hydrolysis, gasification, and carbonization of biomass: a critical review
}

D. Lachos-Perez ${ }^{1}$, A.B. Brown ${ }^{2}$, A. Mudhoo ${ }^{3}$, J. Martinez ${ }^{1}$, M.T. Timko ${ }^{2}$, M.A. Rostagno ${ }^{4}$, T. Forster-Carneiro ${ }^{1, *}$

${ }^{1}$ Department of Food Engineering, University of Campinas (UNICAMP), Rua Monteiro Lobato, n.80, 13083-862 Campinas, SP, Brazil.

${ }^{2}$ Department of Chemical Engineering, Worcester Polytechnic Institute, 100 Institute Road, Goddard Hall 123. Worcester MA 01609, United States of America (USA).

${ }^{3}$ Department of Chemical and Environmental Engineering, Faculty of Engineering, University of Mauritius, Réduit 80837, Mauritius.

${ }^{4}$ School of Applied Sciences, University of Campinas, R. Pedro Zaccaria, 1300, 13484-350, Limeira, SP, Brazil.

\section{HIGHLIGHTS}

$\ddot{y}$ Advances of research trends in development of subcritical and supercritical water processes technologies are reviewed.

$\ddot{y}$ Essential aspects of sub- and supercritical water applied to extraction, hydrolysis, carbonization and gasification processes are discussed.

$\ddot{y}$ Equipment design, process parameters, and types of biomass used for sub- and supercritical water process are presented.

ÿ Bioactive compounds, reducing sugars, hydrogen, biodiesel, and hydrothermal char are the final products of sub- and supercritical water processes.

\section{GRAPHICAL ABSTRACT}

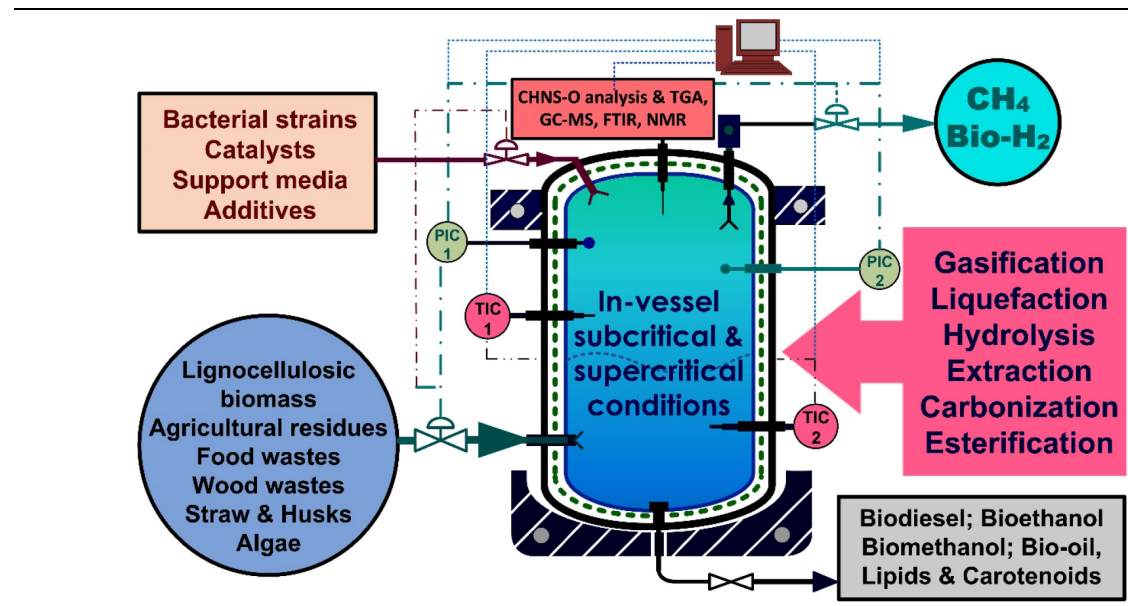

\section{ARTICLE INFO}

\section{Article history:}

Received 26 February 2017

Received in revised form 14 April 2017

Accepted 27 April 2017

Available online 1 June 2017

\section{Keywords:}

Biomass

Subcritical water

Supercritical water

Waste-to-Energy

\begin{abstract}
This review summarizes the recent essential aspects of subcritical and supercritical water technology applied to the extraction, hydrolysis, carbonization, and gasification processes. These are clean and fast technologies which do not need pretreatment, require less reaction time, generate less corrosion and residues, do not use toxic solvents, and reduce the synthesis of degradation byproducts. The equipment design, process parameters, and types of biomass used for subcritical and supercritical water process are presented. The benefits of catalysis to improve process efficiency are addressed. Bioactive compounds, reducing sugars, hydrogen, biodiesel, and hydrothermal char are the final products of subcritical and supercritical water processes. The present review also revisits advances of the research trends in the development of subcritical and supercritical water process technologies.
\end{abstract}

(C) 2017 BRTeam. All rights reserved.

* Corresponding author at: Tel.: +55 1935214041

E-mail address: taniafc@unicamp.br

Please cite this article as: Lachos-Perez D., Brown A.B., Mudhoo A., Martinez J., Timko M.T., Rostagno M.A., Forster-Carneiro T. Subcritical and supercritical water extraction, hydrolysis, gasification and carbonization of biomass: a critical review. Biofuel Research Journal 14 (2017) 611-626. DOI: 10.18331/BRJ2017.4.2.6 


\section{Contents}

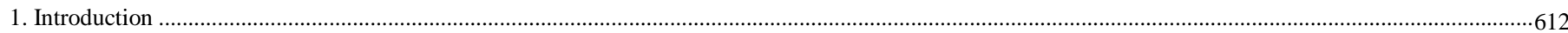

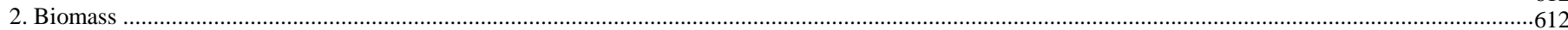

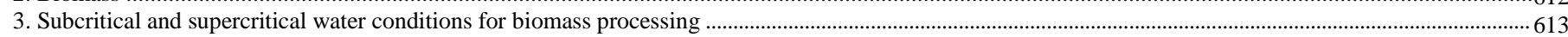

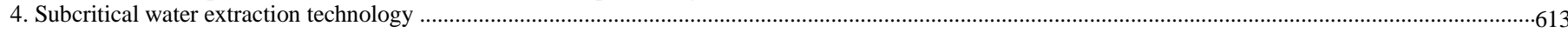

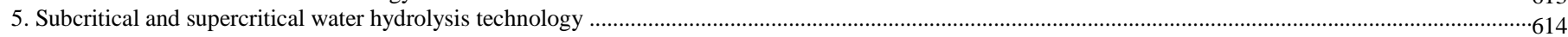

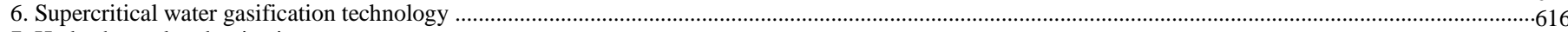

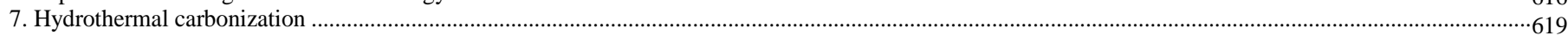

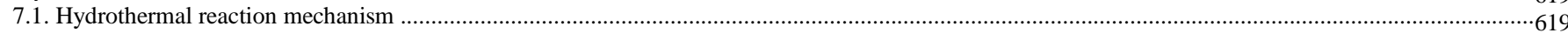

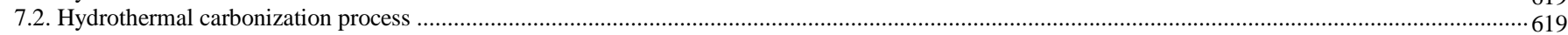

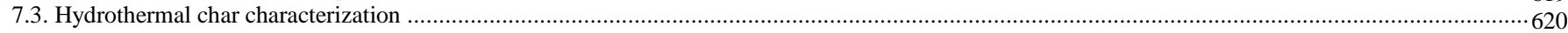

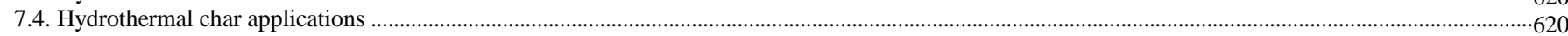

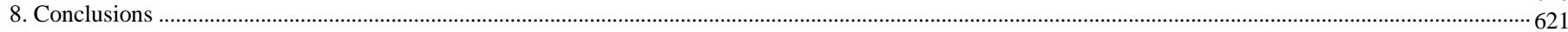

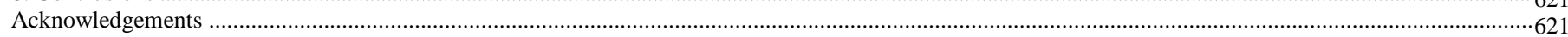

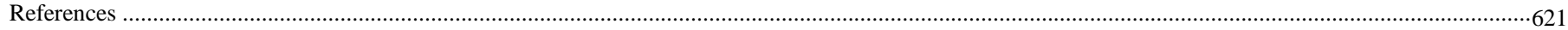

\section{Introduction}

Currently, our society is partially based on the concept of bioeconomy. Currently, our society is partially based on the concept of bioeconomy. Here, the term "bioeconomy" refers to the "sustainable production and conversion of plants into food, fibers, health and industrial products, and energy" (Yamamoto et al., 2014). Biomass-derived fuels have potentials as viable alternatives to petroleum-based fuels in the short to medium terms (Prado et al., 2016). Several techniques have been designed and evaluated for the recovery of bioactive compounds and sugars from natural feedstocks and to produce biogas, biohythane, or valuable carbonized solids from different types of biomass. However, comprehensive experiments and simulations are needed to optimize process parameters before the economic viability may be achieved at industrial scales. For liquid biofuel production, the most pressing challenge is to achieve more effective and benign bioconversion of biopolymers into sugars, since this step requires breaking down the lignocellulosic complex via energy-intensive processing steps.

Conversion of wastes into bioenergy products is especially promising as a method to increase value and minimize the environmental and ecological footprints of existing industrial processes. However, the utilization of renewable or even waste feedstocks does not guarantee that a process is either sustainable or green. To be both sustainable and green, processes must use benign catalysts, solvents, and auxiliary chemicals. Due to the quantities used, the selection of green solvents is especially important for achieving process sustainability. Here, benign solvents include especially those identified as Generally Regarded As Safe (GRAS), a category that includes water, ethanol, $\mathrm{CO}_{2}$, and combinations (Clark and Pfaltzgraff, 2012; Vardanega et al., 2015; Timko et al., 2016a). Different techniques have been developed to streamline and enhance solvation intensity as well as the power and effectiveness of these solvents, including the use of high pressures and (sometimes) high temperatures (Vardanega et al., 2015).

Solvent selection is important for sustainable extraction and reaction processes. Subcritical water, supercritical fluid, and ultrasound-assisted processing are some of the emerging green extraction techniques receiving renewed and sustained research interest among many research groups worldwide. For recovery of sugars from biomass feeds, subcritical and supercritical water hydrolysis have been studied as alternatives that reduce the cost and chemical use of enzymatic, acid, and alkaline processing (Rostagno et al., 2015). The objective of supercritical water gasification is to transform wet biomass to a hydrogen-rich biogas. Supercritical water gasification process is effective at temperatures above its critical point, often around $600{ }^{\circ} \mathrm{C}$ (LachosPerez et al., 2015) and the introduction of a catalyst permits operation at reduced temperatures.

Extraction, hydrolysis, and gasification often co-generate substantial quantities of a carbonaceous char material. Valorizing this material as a coproduct is necessary to achieve favorable economic performance for the overall process. In fact, recent works have shown that processes designed to maximize the yield of solid carbon products (processes that are collectively termed "hydrothermal carbonization" (HTC)) may have economic benefits as standalone technologies. Unlike pyrolysis, HTC is suitable for both wet and dry feedstocks and HTC of the former can result in superior energy balance compared with pyrolysis. The hydrothermal char product of HTC has shown promise in many applications (Libra et al., 2011), including power generation as a "renewable coal" (Mumme et al., 2011), water purification (Regmi et al., 2012) electrochemistry (Wei et al., 2011), and catalysis (Karagöz et al., 2005). This review emphasizes on a fresh perspective of the application of subcritical and supercritical water conditions as environmentally-benign methods to extract, hydrolyze, gasify, and carbonize biomass to produce bioactive compounds, sugars, biogas, and other valuable solids.

\section{Biomass}

The term "biomass" can be defined as the total mass of living or recently dead (unfossilized) organic matters within a given environment. More practically, biomass attributes $\mathrm{b}$ all forms of organic matter potentiallyrecoverable from a variety of renewable sources such as dedicated energy crops and trees, agricultural crops, animal wastes, crop wastes from agricultural activities, wood and municipal wastes, etc. (Olanrewaju, 2012). Most of the biomass used comes from agro-industrial residues, because these are renewable and could be obtained at low-cost or in some cases no cost especially when the raw material is of residue nature. Main residue types are, for example, molasses, bagasse, and maize milling by-products (Pedras, 2015).

Cellulose, hemicellulose, and lignin are the components constituting lignocellulosic biomass. Cellulose is a regular, linear, homopolymer consisting of D-glucose monomers linked by $\beta-(1,4)$ glycosidic bonds. Cellulose is the dominant structural polysaccharide. Plant cellulose is composed of two parts: a crystalline structure (organized) and a nonorganized amorphous structure, also called para-crystalline structure. Individual cellulose polymers are "bundled" together as cellulose fibrils, which are usually independent and weakly connected by hydrogen bonds (Hendriks and Zeeman, 2009). Hemicellulose is a polysaccharide consisting of various sugar monomer units such as xylose, galactose, mannose, arabinose, and also glucose; unlike cellulose, hemicellulose is branched and amorphous. The function of hemicellulose is to bind cellulose and lignin. Lignin is a random, three-dimensional polymer consisting of phenyl-propanoic sub units. Lignin is naturally made of coniferyl alcohol, sinapyl alcohol, and p-coumaryl alcohol, arranged in an irregular structure and is the main source resistance against enzymatic degradation (Pedras, 2015).

For biofuels production, the most economically and technologically significant barrier is conversion of biomass into sugars readily available for microbial action, a process that requires cleaving and dismantling the lignocellulosic complex. Biopolymer breakdown is usually performed via energy intensive processing of the cellulose and hemicellulose fractions contained in the biomass into sugars; while subsequent fermentation processes convert the simple sugars into fuels and/or chemicals. The complex polymer composition of biomass, including cellulose, hemicellulose, and lignin polymers, makes direct and efficient conversion to bioenergy particularly difficult (Zhu et al., 2016). The combination of elevated temperatures and favorable solvent properties makes subcritical/supercritical processing a promising alternative to conventional 


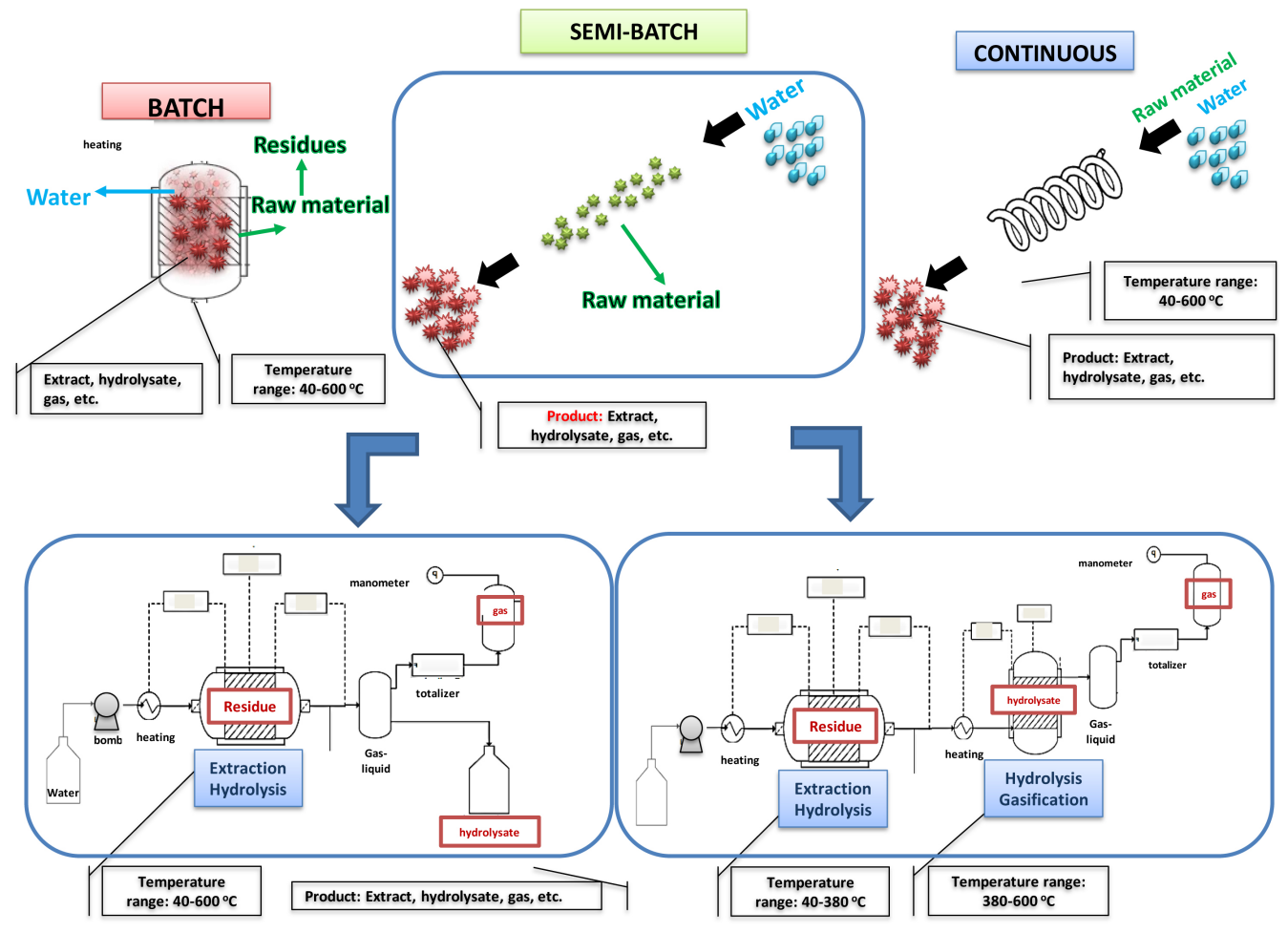

Fig.1. Sub/supercritical water hydrolysis performed in batch, semi-batch, and continuous systems.

biological and chemical processes for decomposition of the lignocellulosic complex (Rostagno et al., 2015).

In addition to the aforementioned biopolymers (cellulose, hemicellulose, and lignin), biomass may also contain proteins, simple sugars, pectins, phenolics, glycosides, saponins, fats, waxes, alkaloids, gums, resins, terpenes, starches, essential oils potassium, sodium and calcium (Yu et al., 2008). These minor components have potential as flavors, fragrances, pharmaceuticals, biomaterials, and nutraceuticals, all of which are more valuable than liquid fuels. Valorization of these minor components can therefore, be an important strategy for improving overall process economics of an integrated biorefinery.

On the other hand, it should be noted that although lignocellulosic biomass is abundant and inexpensive; commercial-scale conversion of lignocellulosic biomass into fuels requires regular delivery of a consistent raw material, a difficult logistic and supply challenge. In fact, overall economics of bio-ethanol production depend heavily on the cost of the feedstock (Davis et al., 2015). Thus, economically viable production of bioethanol requires careful process logistics and supply-chain consideration.

\section{Subcritical and supercritical water conditions for biomass processing}

The properties of any pure substances are dependent on temperature and pressure. When a pure substance enters the supercritical state, it is in fact heated and pressurized to temperatures and pressures greater than its critical point. For water, the critical temperature is $374{ }^{\circ} \mathrm{C}$ and the critical pressure is $22.1 \mathrm{MPa}$ (Taylor et al., 2001; Elliott et al., 2015). Industrial applications that use water at the critical temperature and critical pressure are generally suffering from very high costs due to the high-pressure equipment and the energy to be applied. For this reason, careful engineering experiments and design are required to optimize processes based on supercritical water in order to reduce capital and operating costs. The motivation to study subcritical and supercritical conditions stems from the fact that such processing conditions possess some of the advantages embodied in the green chemistry and green chemical engineering concepts, namely, better energy efficiency and energy savings, minimization of wastes generation, improved atom economy, and better interphase mass transfer coefficients.
Subcritical/supercritical water extraction, hydrolysis, gasification, and carbonization can be carried out in batch, semi-batch and continuous systems (Fig. 1). When the raw material(s) (biomass) and reaction solvent (water) are placed inside a close reactor, the process is defined as batch. On the other hand, when biomass is brought into contact with a continuous flow of the reaction medium, the process is known as a semi-batch. In the continuous process, both the biomass feed and the solvent are continuously entering and exiting the reactor. Rapid reaction rates achievable by operation at high temperatures can be advantageous for continuous processing (Williams and Onwudili, 2005). For example, Elliott et al. (2015) reported yield improvements when converted a batch process to continuous operation. Since the carbon and energy recovery efficiency can be favorable, a considerable deal of interest exists for commercial application of supercritical water technologies in the continuous mode. On the contrary, the technical difficulties associated with pumping biomass slurries has made most studies focus on subcritical and supercritical processes that are performed using batch or semi batch systems. As result, many technical hurdles need to be addressed to determine the optimal scale of continuous systems. Furthermore, integration of several semi-batch processes into a simulated continuous operation at the industrial level may be preferred over batch or continuous operation.

In addition to the type of reactor (batch, continuous, or semicontinuous), several other factors also influence the performance of subcritical and supercritical water hydrolysis, chiefly; feedstock properties, solvent properties, reactor configurations, time-temperature behavior of reacting particles, as well as the use of catalysts and other reagents. Some of these factors will be discussed later.

\section{Subcritical water extraction technology}

Plant materials contain many useful compounds such as flavors, fragrances, pharmaceuticals, and dietary supplements. To use the compounds present in the biomass, they must first be separated from the rest of the raw materials. The typical extraction process involves using a solvent (liquid or gas) to selectively remove and/or dissolve target 
compounds from the raw material matrix (i.e., the biomass). The process can be performed using different types of extraction systems and several variables will affect the efficiency and selectivity of the process, including raw material and target compounds characteristics, temperature, extraction solvent, solvent to feed ratio, etc.

Solvent characteristics play a major role in the selectivity of the process affecting both target compound selectively and - to a lesser extent - mass transfer rates. Water alone or as part of a mixture of miscible solvents is primarily used for extracting polar to moderately polar compounds. Water is used as a solvent for several extraction processes focusing on the recovery of useful and potentially valuable compounds from diverse biomass types. Due to their polarity, antioxidants, phenolic compounds, and carbohydrates are among the most common compounds extracted using water as solvent (Table 1). In general, an increase in the extraction temperature increases extraction rate by increasing diffusion constants, increasing solubility, and swelling the biomass matrix. The last stage of the extraction process is controlled by diffusion and can be most effectively improved the most by increasing extraction temperature (Rostagno and Prado, 2013). Solubility of compounds in the solvent is also affected by temperature. It has been shown that the solubility of gallic acid, cathechin, and protocatechuic acid in water would increase by more than 200 times when the temperature was increased from $25^{\circ} \mathrm{C}$ to $142^{\circ} \mathrm{C}$ (Srinivas et al., 2010).

When using water as solvent for extraction processes performed at ambient pressure, extraction temperature is limited to the normal boiling point of water $\left(100^{\circ} \mathrm{C}\right)$. In contrast, in pressurized systems, the process can be performed above the boiling point of the solvent. Usually high-pressure extraction processes using water are performed using temperatures up to $150^{\circ} \mathrm{C}$. Increasing extraction temperature greater than $100^{\circ} \mathrm{C}$ affects the characteristic of water as a solvent, modifying its dielectric constant and viscosity. As a result, the water solubility of mid-polar compounds increases with increasing temperature, allowing water to replace or reduce the amount of organic solvent such as methanol and ethanol used for extraction (Çam and Hış11, 2010).

The scope for increasing process temperature to improve extraction efficiency depends on the thermal stability of target compounds. Polyphenols, a class of compounds with high antioxidant capacity and biological effects, are an example of temperature-sensitive natural products. For recovery of phenolics from pomegranate peels, extraction temperature should not be greater than $40^{\circ} \mathrm{C}$, as this temperature optimizes solubility and extraction rates while minimizing thermal degradation (Çam and Hış11, 2010). Sugarcane bagasse is another example. Bagasse contains many compounds of potential value, including polyphenols which must be extracted at conditions which minimize thermal degradation (Zhao et al., 2015). In contrast, temperatures as great as $190^{\circ} \mathrm{C}$ can be used for the extraction of non-cellulosic heteropolysaccharides composed of xylose, glucose, galactose, mannose, arabinose, and smaller amounts of 4-O-methylglucuronic acid compared with sugarcane. The interest in the recovery of these compounds is to use them as water-soluble polymers to replace synthetic polymers in food packaging, wound dressings, and drug capsules (Jayapal et al., 2013; Banerjee et al., 2014).

For thermally-stable compounds, the scope for increasing extraction temperature to improve extraction efficiency and reduce extraction time is greatly increased compared with thermally labile compounds. In fact, subcritical water is employed in the extraction of several classes of phenolics from different biomass, including citrus peel, pomegranate seed residues, flaxseed meal sticks, sour cherry pomace, and onion skin among other examples (Chienthavorn and Insuan, 2004; Adil et al., 2008; Ko et al., 2011; Cheigh et al., 2012; Kanmaz, 2014). Subcritical water has also been used for the extraction of antioxidants from eucalyptus biomass, canola meal, onion peel, winery wastes, grape pomace spent coffee grounds, and silver skin, just to name a few examples (Kulkarni et al., 2008; Hassas-Roudsari et al., 2009; Aliakbarian et al., 2012; Narita and Inouye, 2012; Vergara-Salinas et al., 2013; Lee et al., 2014; Zeković et al., 2014; Xu et al., 2015). For many compounds and raw materials, subcritical water extraction efficiencies and yields are usually greater than what can be obtained with organic solvents using conventional techniques.

In some applications, acids have been used to modify water to improve extraction efficiency for some compounds. For example, anthocyanins, a valuable class of compounds present in blackberry residues, are extracted most efficiently using acidified water and temperatures between 60 and $80{ }^{\circ} \mathrm{C}$. The remaining phenolics of blackberry residues could then be extracted by increasing the temperature and by a using alcohol/water mixture as the extraction solvent (Machado et al., 2015). This example implies the importance of the optimization of acidity for recovery of a specific target compound.

\section{Subcritical and supercritical water hydrolysis technology}

Decomposition of cellulose and hemicellulose into pure sugar streams is the major technical and economic bottleneck limiting commercialization of biofuels. Conventional technologies to convert biomass into sugars, including dilute acid treatment, steam explosion, and enzymatic hydrolysis, have been extensively studied in recent years (Agudelo et al., 2016; Jiang et al., 2016; Li et al., 2016b; Romero-García et al., 2016; Kapoor et al., 2017; Qin et al., 2017). Currently, acid and enzymatic hydrolysis processes are used in the synthesis of second-generation bioethanol. However, acid hydrolysis requires neutralization of the medium afterwards, and the use of enzymes is restricted due to their high cost and the operational processing steps (Li et al., 2016a). Compared with dilute acid pretreatment, hydrothermal technologies, especially those based on subcritical and subcritical water, could be used for decomposition of biomass into simple sugars with high yields (Shitu et al., 2015). Due to their environmentallybenign characteristics and abundance, water and $\mathrm{CO}_{2}$ are mostly used in reactions at subcritical and supercritical conditions for agricultural biomass residue processing.

Hydrothermal processing can be divided into two categories - those that are performed at supercritical conditions and those that are performed at supercritical conditions. Subcritical water hydrolysis is usually conducted in a temperature range of 100 to $374^{\circ} \mathrm{C}$ under sufficient pressure to keep water in the liquid state (Yoshida et al., 2015; Lachos-Perez et al., 2016). Subcritical water treatment aims at utilizing the waste biomass to generate raw materials for new products and a concomitant reduction in waste streams volumes. Supercritical water processing is performed at temperatures greater than $374^{\circ} \mathrm{C}$ and typically at pressures greater than 25 $\mathrm{MPa}$. At these conditions, water behaves as a single non-condensable phase, with a density close to a liquid and transport properties similar to a gas (Marrone and Hong, 2009).

Hydrothermal treatment offers several advantages, including rapid reaction rates and replacement of acids/bases with a more environmentallyacceptable solvent. In addition, many feeds of interest are moist and the water contained in the raw material and/or organic residue may be used as the reaction medium; compatibility with moist feeds eliminates the need of a drying step used in conventional methods.

Despite the existing potentials, the application of supercritical fluid technology to agricultural waste is still under development. A particular challenge is that hydrolysis rates and sugar yields depend on the characteristics of the residues, composition and structure of the cell wall, and the type of the monosaccharides present in the feed. As a result, each raw material must be studied individually, each new feed representing a new set of technological challenges (Prado et al., 2014).

The three main components of biomass respond differently to hydrothermal treatment. Hemicellulose is the most readily hydrolyzed fraction. Kim et al. (2014) found that $60-70 \%$ of the pentose content of hardwood could be recovered at mild conditions $\left(<200^{\circ} \mathrm{C}\right)$, but that recovery of the remaining pentose content required more severe treatment. Pińkowska et al. (2011) studied hydrothermal decomposition of xylan as a model compound for hemicellulose. They reported the maximum soluble sugar yield at $220-235^{\circ} \mathrm{C}$ and within the shortest residence time studied ( 0 min, i.e., heating the reactor to reaction temperature followed by immediate cooling). Increasing the temperature or residence time decreased sugar yields, as sugar decomposition and re-combination became increasingly important.

Cellulose is generally more recalcitrant to hydrolysis than hemicellulose. Sasaki et al. (2000) studied dissolution and hydrolysis of cellulose in supercritical water, arguing that at $400^{\circ} \mathrm{C}$ cellulose was mainly decomposed to form hydrolysis products but at temperatures from 320 to $350^{\circ} \mathrm{C}$, primary hydrolysis products were decomposed. The same group of authors studied cellulose dissolution using a diamond anvil cell, finding that individual cellulose particles became gradually smaller with increasing reaction time at $\mathrm{T}<280^{\circ} \mathrm{C}$ but rapidly disappeared at $\mathrm{T}>320^{\circ} \mathrm{C}$. Sakaki et al. (2002) reported nearly $100 \%$ cellulose decomposition after $12 \mathrm{~min}$ at $295^{\circ} \mathrm{C}$, resulting in a product consisting of a water soluble fraction $(81 \mathrm{wt} . \%)$ and 
Table 1.

Highlights of the results on biomass application for the production of bioactive compounds under subcritical water extraction.

\begin{tabular}{|c|c|c|c|c|}
\hline Raw material & Target compounds & Extraction technique & Highlights of results & Reference \\
\hline Blackberry residues & $\begin{array}{l}\text { Polyphenols and Antioxidants - } \\
\text { Anthocyanins }\end{array}$ & $\begin{array}{l}\text { Solvent: water, acidified water } \mathrm{pH}=2.5 \text {, } \\
\text { ethanol and ethanol + water } 50 \% \text { (v:v) } \\
\text { Temperature: } 60,80 \text {, and } 100{ }^{\circ} \mathrm{C} \\
\text { Pressure: } 7.5 \mathrm{MPa}\end{array}$ & $\begin{array}{l}\text { Recovery of phenolics was significantly enhanced } \\
\text { at higher temperatures. Higher extraction yields } \\
\text { recorded for anthocyanins with acidified water at } 60 \\
\text { and } 80^{\circ} \mathrm{C} \text {. }\end{array}$ & Machado et al. (2015) \\
\hline Pomegranate peels & $\begin{array}{l}\text { Polyphenols and Antioxidants - } \\
\text { Punicalagin and Ellagic acid } \\
\text { derivatives }\end{array}$ & $\begin{array}{l}\text { Solvent: water } \\
\text { Temperature: } 40,65 \text {, and } 90{ }^{\circ} \mathrm{C} \\
\text { Extraction time (static): } 5,15 \text {, and } 30 \mathrm{~min} \\
\text { Pressure: } 102.1 \mathrm{~atm} \\
\text { Flush volume: } 5-100 \mathrm{~mL}\end{array}$ & $\begin{array}{l}\text { Temperatures higher than } 40{ }^{\circ} \mathrm{C} \text {, longer extraction } \\
\text { times, and larger particles reduced extraction yield. } \\
\text { Pressurized water augmented the yield in } \\
\text { comparison with methanol, ethanol, and acetone. }\end{array}$ & Çam and Hışıl (2010) \\
\hline
\end{tabular}

$\begin{array}{llll} & \text { Phenolic compounds, Gallic acid, } & \text { Solvent: water } & \text { Best extraction yields at } 160 \text { to } 180{ }^{\circ} \mathrm{C}, 6 \mathrm{MPa} \text {, and } \\ \text { Potato peel } & \begin{array}{l}\text { Chlorogenic acid, Caffeic acid, } \\ \text { Protocatechuic acid, Syringic acid, }\end{array} & \text { Temperature: } 100 \text { to } 240{ }^{\circ} \mathrm{C} & \text { Pressure: } 6 \mathrm{MPa} \\ & \begin{array}{l}\text { p-hydroxyl benzoic acid, Ferulic } \\ \text { acid, and Coumaric acid }\end{array} & \text { Flow-rate: } 2 \mathrm{~mL} / \mathrm{min} & 60 \text { min. Chlorogenic acid and gallic acid were } \\ & \text { Residence time: } 30-120 \mathrm{~min} & \text { essential components extracted at } 180{ }^{\circ} \mathrm{C} \text {. }\end{array}$

\begin{tabular}{|c|c|c|c|c|}
\hline Sugar cane bagasse & $\begin{array}{l}\text { Hemicellulose components } \\
\text { (arabinoxylans) }\end{array}$ & $\begin{array}{l}\text { Solvent: water } \\
\text { Temperature: } 170,180,190 \text {, and } 200{ }^{\circ} \mathrm{C} \\
\text { Extraction time: } 15 \mathrm{~min} \\
\text { Pressure: not specified }\end{array}$ & $\begin{array}{l}\text { Increasing temperatures increased release of } \\
\text { polymeric hemicellulose but decreased lignin } \\
\text { extraction. }\end{array}$ & Banerjee et al. (2014) \\
\hline
\end{tabular}

\begin{tabular}{|c|c|c|c|c|}
\hline $\begin{array}{l}\text { Pomegranate seed } \\
\text { residues }\end{array}$ & $\begin{array}{l}\text { Total phenolic compounds } \\
\text { (antioxidant capacity) }\end{array}$ & $\begin{array}{l}\text { Solvent: water (high pressure); water } \\
\text { methanol, ethanol and acetone (low pressure) } \\
\text { Extraction time: } 15-120 \mathrm{~min} \\
\text { Temperature: } 80-280{ }^{\circ} \mathrm{C} \text {; } \\
\text { Solid to water ratio: } 1: 10-1: 50(\mathrm{~m} / \mathrm{v}) \\
\text { Pressure: } 6.0 \mathrm{MPa}\end{array}$ & $\begin{array}{l}\text { Increasing extraction temperatures increased the } \\
\text { total phenolic content in extracts. Optimum } \\
\text { extraction occurred at } 220^{\circ} \mathrm{C} \text { for water to solids } \\
\text { ratio of } 40 .\end{array}$ & He et al. (2012) \\
\hline Citrus peel & $\begin{array}{l}\text { Phenolic compounds - Flavanones } \\
\text { hesperidin and narirutin }\end{array}$ & $\begin{array}{l}\text { Temperature: } 110-200^{\circ} \mathrm{C} \\
\text { Extraction time: } 5-20 \mathrm{~min} \\
\text { Pressure: } 100 \mathrm{~atm} .\end{array}$ & $\begin{array}{l}\text { Peak extraction yield at } 160^{\circ} \mathrm{C} \text { for extraction time } \\
\text { of } 10 \mathrm{~min} \text {. }\end{array}$ & Cheigh et al. (2012) \\
\hline
\end{tabular}

Solvent: water (high pressure); water methanol and ethanol (low pressure): Temperature: $100-190^{\circ} \mathrm{C}$

Extraction time: $5-30 \mathrm{~min}$

Ratio of the mixture sample and

Ratio of the mixture sample and
diatomaceous earth: $0.5: 3.5-2: 2$

Pressure: 90-131 bar.
Peak extraction yield for quercetin obtained at 165 ${ }^{\circ} \mathrm{C}$, and for 15 min of extraction time. Extraction yield with water was significantly greater that those Ko et al. (2011) recorded with methanol, ethanol and water-atboiling-point

\begin{tabular}{|c|c|c|c|c|}
\hline Flaxseed meal & $\begin{array}{l}\text { Lignan secoisolariciresinol } \\
\text { diglucoside (SDG), Total phenolics } \\
\text { and total flavonoids }\end{array}$ & $\begin{array}{l}\text { Solvent: water } \\
\text { Temperature: } 160,170 \text {, and } 180^{\circ} \mathrm{C} \\
\text { Extraction time: } 5,15,30 \text {, and } 60 \mathrm{~min}\end{array}$ & $\begin{array}{l}\text { Higher extraction temperatures of } 170 \text { and } 180^{\circ} \mathrm{C} \\
\text { decreased yields by less than } 10 \% \text { but impacted on } \\
\text { extraction time reductions much more significantly. } \\
\text { Total phenolics and total flavonoids were best } \\
\text { extracted at } 180^{\circ} \mathrm{C} \text { for } 15 \text { min. }\end{array}$ & Kanmaz (2014) \\
\hline winery wastes & Total polyphenols and flavonoids & $\begin{array}{l}\text { Solvent: water } \\
\text { Temperature: } 100,120 \text {, and } 140{ }^{\circ} \mathrm{C} \\
\text { Pressure: } 8,11.5 \text {, and } 15 \mathrm{MPa}\end{array}$ & $\begin{array}{l}\text { Extraction yield potentially to reach its maximum at } \\
140{ }^{\circ} \mathrm{C} \text { and } 11.6 \mathrm{MPa} \text {. Subcritical water gave much } \\
\text { higher yields than ethanol and water under } \\
\text { atmospheric conditions. }\end{array}$ & Aliakbarian et al. (2012) \\
\hline Grape Pomace & $\begin{array}{l}\text { Phenolic compounds - tannins, } \\
\text { anthocyanins, and croanthocyanidin }\end{array}$ & $\begin{array}{l}\text { Solvent: water } \\
\text { Temperature: } 50-200{ }^{\circ} \mathrm{C} \\
\text { Extraction time: } 5-30 \mathrm{~min}\end{array}$ & $\begin{array}{l}\text { Optimum extraction for anthocyanins obtained at } \\
100^{\circ} \mathrm{C} \text {. Higher temperatures and longer extraction } \\
\text { times considerably lowered extraction yields of } \\
\text { phenolics. Proanthocyanidin was extracted only } \\
\text { below } 100^{\circ} \mathrm{C} \text {. }\end{array}$ & $\begin{array}{l}\text { Vergara-Salinas et al. } \\
\text { (2013) }\end{array}$ \\
\hline $\begin{array}{l}\text { Apple pomace and citrus } \\
\text { peel }\end{array}$ & Pectin & $\begin{array}{l}\text { Solvent: water } \\
\text { Solid to liquid ratio of } 1: 30 . \\
\text { Temperature: } \\
\text { Apple pomace: } 130-170^{\circ} \mathrm{C} \\
\text { Citrus peel } 100-140^{\circ} \mathrm{C} \\
\text { Extraction time: } 5 \mathrm{~min}\end{array}$ & $\begin{array}{l}\text { Optimum extraction temperature was } 120^{\circ} \mathrm{C} \text { for } \\
\text { citrus peel. } \\
\text { With apple pomace substrate, optimum extraction } \\
\text { was obtained at } 150^{\circ} \mathrm{C} \text {. }\end{array}$ & Wang et al. (2014) \\
\hline
\end{tabular}

a solid deposit (18 wt.\%). Sasaki et al. (2004) later studied cellulose decomposition in a continuous flow microreactor and successfully reproduced their data using an empirical kinetic model. Ehara and Saka (2002) studied supercritical water hydrolysis of microcrystalline cellulose in batch and flow reactors, finding that the flow system decreased sugar degradation but that glucose yield was maximized in the batch reactor. Later, Ehara and Saka (2005) suggested sequential supercritical and subcritical water treatment to maximize cellulose hydrolysis and minimize sugar degradation. More recently, Cantero et al. (2013) studied ultra-fast reaction conditions $(<0.1$ s) for cellulose hydrolysis, reporting $>96 \%$ yield of total mono/oligo 
saccharides at $400^{\circ} \mathrm{C}$; with minimal $(5 \mathrm{ppm})$ production of 5hydroxymethylfurfural degradation product.

Lignin is the most recalcitrant of the three main biomass polymers and its hydrothermal decomposition has been studied mainly at temperatures greater than $300^{\circ} \mathrm{C}$ (Ma et al., 2016). For example, Yong and Matsumura (2012) studied decomposition of lignin in a flow reactor over the temperature range of 390 to $480^{\circ} \mathrm{C}$ and at residence times from 0.5 to $40 \mathrm{~s}$, claiming complete decomposition within 5 s. Pińkowska et al. (2012) studied hydrothermal treatment of alkali lignin over the temperature range of 280 to $390^{\circ} \mathrm{C}$. The authors found the greatest yields of stable phenol and cresol products at $280^{\circ} \mathrm{C}$ Barbier et al. (2012) performed a detailed analysis of the products of lignin decomposition in sub- and supercritical water $\left(370-390^{\circ} \mathrm{C}\right)$ and concluded that the mechanism consisted of a complex network of parallel and sequential fragmentation and re-condensation reactions. In their studies of model lignin compound decomposition, Kanetake et al. (2007) found that guaiacol completely was decomposed within $100 \mathrm{~min}$ (at 380 to $400^{\circ} \mathrm{C}$ ), producing catechol as the main product. Yong and Yukihiko (2013) studied guaiacol decomposition at short residence times $(0.5$ to $40 \mathrm{~s})$ and under conditions of rapid heating. They confirmed rapid guaiacol decomposition, leasing to char, gas, phenolic, and benzene production. At temperatures greater than the critical point, Yong and Yukihiko (2013) observed formation of polycyclic aromatic hydrocarbons.

The majority of studies on sub- and supercritical hydrolysis have focused on different types of whole biomass. Most studies on hydrolysis suggest that $(1,4)-$ glycosidic linkages contained in cellulose break most rapidly under supercritical conditions, resulting in higher yields of mono- and oligosaccharides than under subcritical conditions. The main hydrolysis products are water-soluble oligomers (celohexose, celopentose, celotetraose, cellotriose, and cellobiose), monomers (glucose and fructose), and decomposition products of these monomers (1,6-anhydroglucose, glyceraldehyde, erythrose, glycolaldehyde, dihydroxyacetone, 5hydroxymethyl-furaldehyde (5-HMF), and organic acids). The generation of soluble sugars from rice bran was reported by Pourali et al. (2010), who applied hydrothermal process conditions to decompose rice bran at different reaction temperatures and times in a batch reactor. They observed the greatest yields of water-soluble sugars at $220^{\circ} \mathrm{C}$, and these sugars were primarily oligomers and monomers. Likewise, Shimanouchi et al. (2014) recovered reducing sugars from Carya cathayensis Sarg Peel (CCSP) under subcritical water at different reaction temperatures, and also reported that the optimal temperature for formation of reducing sugars was $190^{\circ} \mathrm{C}$. Mohan et al. (2015) studied the conversion of bamboo to total reducing sugars by hydrolysis in subcritical water using a batch reactor at temperatures of 170 to $200^{\circ} \mathrm{C}$ for $40 \mathrm{~min}$, obtaining a maximum yield of $42.21 \%$ at $180^{\circ} \mathrm{C}$ after 25 min of reaction. Prado et al. (2014) studied the conversion of several agro-industrial residues in a semi-continuous reactor $(50 \mathrm{~mL})$ by hydrolysis with subcritical water $(208$ and $257^{\circ} \mathrm{C}$ ) for $30 \mathrm{~min}$ at a flow rate of $33 \mathrm{~mL} / \mathrm{min}$ and pressure of $20 \mathrm{MPa}$. Their results indicated that for palm fiber hydrolysis, increasing the temperature reduced the yield of rafinose $(0.1 \%)$ and increased the yield of glucose $(0.7 \%)$, and 5-HMF $(0.8 \%)$. However, the yield of sugars from coconut husk in this work did not change with temperature, and in the case of grape seed, the yield of sugars was calculated to be about $1.0 \%$. All of these studies indicate that subcritical/supercritical water hydrolysis processes should be evaluated individually for each raw material.

Selecting reactor conditions to optimize sugar yield is important in order to balance biopolymer hydrolysis rates and sugar degradation rates, both of which increase with increasing temperature. For example, Lin et al. (2015) studied the competitive reactions involved in sugar production and degradation from rice straw substrates at concentrations of 2.5 and $10 \mathrm{wt} . \%$ in a batch reactor containing subcritical water at temperatures from 250 to $300^{\circ} \mathrm{C}$, at pressures ranging from 12 to $20 \mathrm{MPa}$, and stirring speeds between 100 and $300 \mathrm{rpm}$. In their study, the greatest yield was $0.346 \mathrm{~g} / \mathrm{g}$ of rice straw and least sugar breakdown was obtained at $280^{\circ} \mathrm{C}, 5 \% \mathrm{w} / \mathrm{w}, 20 \mathrm{MPa}$, and $200 \mathrm{rpm}$. In addition, increasing the temperature to $300^{\circ} \mathrm{C}$ decreased the yield, which the authors attributed it to the degradation of primary sugars to form acetic acid and 2methyltetrahydrofuran (Lin et al., 2015). Zhu et al. (2016) studied the conversion of corn ear to reducing sugars by hydrothermal treatment at 190$320^{\circ} \mathrm{C}$. Their results showed complete degradation of hemicellulose and cellulose, with sugars yields varying between $5.15 \%$ and $13.31 \%$. These results indicated that hemicellulose was hydrolyzed most readily, and once hemicellulose was depleted, the hydrolysis of the cellulose started; however, degradation of the produced reducing sugars was faster than the degradation of the cellulose. The combination of supercritical conditions as first stage and subcritical conditions as second stage showed better results than those obtained in separate sub- or supercritical treatments and greater control of product degradation was achieved (Ehara and Saka, 2005; Li et al., 2016a).

Another strategy to tune reaction rates independently of temperature is to adjust the $\mathrm{pH}$ of the solution phase. Carbon dioxide $\left(\mathrm{CO}_{2}\right)$ can be added to acidify subcritical and supercritical water to increase reaction rates. $\mathrm{CO}_{2}$ reacts with water to form carbonic acid, releases protons to acts as a catalyst for hydrolysis reactions (Rogalinski et al., 2008), as shown in :

$$
\mathrm{CO}_{2}+\mathrm{H}_{2} \mathrm{O} \leftrightarrow \mathrm{H}_{2} \mathrm{CO}_{3} \leftrightarrow \mathrm{H}^{+}+\mathrm{HCO}_{3}^{-} \leftrightarrow 2 \mathrm{H}^{+}+\mathrm{CO}_{3}^{2-}
$$

The addition of $\mathrm{CO}_{2}$ as acid catalyst is advantageous as the acid is released during de-pressurization and does not require a neutralization step which would generate waste. Investigations on the addition of $\mathrm{CO}_{2}$ showed that it increases hydrolysis rates, increases the yield of monomers, decreases the molecular weight distribution of the product, and apparently decreases the formation of degradation products (Miyazawa and Funazukuri, 2005; Schacht et al., 2008; Liang et al., 2016; Prado et al., 2017).

\section{Supercritical water gasification technology}

Gasification with supercritical water can break large biomass molecules into smaller molecules such as carbon monoxide $(\mathrm{CO})$, methane $\left(\mathrm{CH}_{4}\right)$, hydrogen $\left(\mathrm{H}_{2}\right)$, and $\mathrm{CO}_{2}$ because supercritical water is an adequate reaction medium for the hydrolysis reaction and subsequent gasification. The overall reaction is endothermic at temperatures greater than $680^{\circ} \mathrm{C}$ and is slightly exothermic at temperatures less than $680^{\circ} \mathrm{C}$ (Castello and Fiori, 2011). Hydrogen is generally the target product of biomass gasification. Hydrogen is considered entirely clean as a fuel, given the fact that its combustion produces water only. Hydrogen production from steam gasification is highly economic and effective with low environmental impacts.

Supercritical water gasification is a relatively new process. Treatment of a variety of agricultural wastes at temperatures near $600^{\circ} \mathrm{C}$ and in the presence of supercritical water produces a gas rich in hydrogen (recently termed as 'biohythane') (Peterson et al., 2008). One of the main characteristics of supercritical water gasification is the reduced coal and tar formation compared with conventional technologies which has aroused initial interest in supercritical water gasification. In addition, supercritical water gasification is associated with relatively higher reaction efficiencies and yields as compared with conventional gasification methods, mainly with respect to hydrogen production due to the presence of water in the medium, without the need for a biomass drying step. Therefore, the conversion of moist biomass containing $90 \%$ of water in the gasification process seems to be a sustainable technological option (Calzavara et al., 2005).

Some of the vital reactions that take place in supercritical water biomass gasification are summarized in Equation 2 (Guo et al., 2010; Reddy et al., 2014)

$$
\mathrm{CH}_{x} \mathrm{O}_{y}+(2-y) \mathrm{H}_{2} \mathrm{O} \rightarrow \mathrm{CO}_{2}+(2-y+x / 2) \mathrm{H}_{2}
$$

where $x$ and $y$ are the elemental molar ratio of $\mathrm{H} / \mathrm{C}$ and $\mathrm{O} / \mathrm{C}$ in the biomass, respectively. The product of the reaction is synthesis gas, whose quality depends on $x$ and $y$ (Guo et al., 2010). In addition to Equation 2, other intermediate reactions may also occur during gasification of biomass in supercritical water (Eqs. 3-11):

- $\quad$ Steam reforming reaction

$\mathrm{CH}_{\mathrm{x}} \mathrm{O}_{\mathrm{y}}+(1-\mathrm{y}) \mathrm{H}_{2} \mathrm{O} \rightarrow \mathrm{CO}+(1-\mathrm{y}+\mathrm{x} / 2) \mathrm{H}_{2}$

- Cellulose hydrolysis reaction

$\left(\mathrm{C}_{6} \mathrm{H}_{10} \mathrm{O}_{5}\right)_{\mathrm{n}}+\mathrm{nH}_{2} \mathrm{O} \rightarrow \mathrm{nC}_{6} \mathrm{H}_{12} \mathrm{O}_{6}$

- $\quad$ Glucose reaction

$$
\mathrm{C}_{6} \mathrm{H}_{12} \mathrm{O}_{6} \rightarrow 6 \mathrm{CO}+6 \mathrm{H}_{2}
$$


- Lignin hydrolysis reaction

$\left(\mathrm{C}_{10} \mathrm{H}_{10} \mathrm{O}_{3}\right)_{n}+\mathrm{nH}_{2} \mathrm{O} \rightarrow \mathrm{nC}_{10} \mathrm{H}_{12} \mathrm{O}_{4} \rightarrow$ phenolic

- Phenol steam reforming reaction

Phenol $+\mathrm{H}_{2} \mathrm{O} \rightarrow \mathrm{CO}+\mathrm{CO}_{2}+\mathrm{H}_{2}$

- Steam change reaction

$\mathrm{CO}+\mathrm{H}_{2} \mathrm{O} \leftrightarrow \mathrm{CO}_{2}+\mathrm{H}_{2}$

- $\quad \mathrm{CO}$ methanation reaction

$\mathrm{CO}+3 \mathrm{H}_{2} \leftrightarrow \mathrm{CH}_{4}+\mathrm{H}_{2} \mathrm{O}$

- $\mathrm{CO}_{2}$ - methane reaction

$$
\mathrm{CO}_{2}+4 \mathrm{H}_{2} \leftrightarrow \mathrm{CH}_{4}+2 \mathrm{H}_{2} \mathrm{O}
$$

- Hydrogenation reaction $\mathrm{CO}+2 \mathrm{H}_{2} \leftrightarrow \mathrm{CH}_{4}+0.5 \mathrm{O}_{2}$

Reducing the biomass particle size, increasing the reaction temperature, or increasing the steam-to-biomass ratio could promote $\mathrm{H}_{2}$ yield and increases gasification rates. Many experimental studies have shown that temperatures from 500 to $700^{\circ} \mathrm{C}$ have a significant impact on yields and compositions of gases evolved, but values above the critical point have significantly much less influence on gas compositions. Pressure and residence time are other important control parameters of the supercritical gasification process. With increasing pressure, the ionic product of the water increases, and consequently the rate of hydrolysis also increases. In addition, high pressure was found to improve the steam change reaction, but reduce the rate of decomposition reactions (Guo and Faghri, 2007). The optimization of $\mathrm{H}_{2}$ generation from processes conducted under supercritical gasification regimes using water and corncob biomass was investigated using the orthogonal experimental design technique by $\mathrm{Lu}$ et al. (2012). They found that temperature yielded a greater influence on the process compared with pressure, concentration of feedstock, and addition of an oxidizer. Acid hydrolysis of the feedstock increased $\mathrm{H}_{2}$ yield in contrast to the addition of an oxidizer, which increased the carbon gasification efficiency but not hydrogen yield.

Temperature is a very important parameter and has significant effect on the biomass gasification in supercritical water, particularly when there are no catalysts involved. Lee et al. (2002) studied the gasification of glucose in supercritical water conditions and observed increasing $\mathrm{H}_{2}$ and $\mathrm{CO}_{2}$ yields with increasing temperature. In another work, a $30 \%$ increase in the reaction temperature to $650^{\circ} \mathrm{C}$, increased the carbon efficiency and gasification efficiency by $167 \%$ and $300 \%$, respectively (Hao et al., 2003).

$\mathrm{Lu}$ et al. (2006) studied the production of hydrogen as a function of increasing pressure to $30 \mathrm{MPa}$, and the results obtained showed that carbon and gasification efficiency were independent of pressure. Williams and Onwudili (2005) studied glucose gasification in supercritical water, and reported $90 \%$ conversion after $120 \mathrm{~min}$. On the other hand, Basu and Mettanant (2009) demonstrated that increasing residence time of supercritical water gasification $\left(650^{\circ} \mathrm{C}\right.$ and $\left.30 \mathrm{MPa}\right)$ of rice husks increased hydrogen yield from 7 to $14 \mathrm{~mol}$ $\mathrm{kg}^{-1}$. Lee et al. (2002) studied the influence of residence time on gas yield from gasification of $0.6 \mathrm{M}$ glucose at $28 \mathrm{MPa}$ and $700^{\circ} \mathrm{C}$, showing a high yield of hydrogen regardless of the residence time, provided that the residence time was greater than $10.4 \mathrm{~s}$. Safari et al. (2016) gasified almond shell, wheat straw, and walnut shell in supercritical water for hydrogen production, and observed that increasing the reaction time up to $30 \mathrm{~min}$ increased the hydrogen yield and gasification efficiency.

Subcritical and/or supercritical processing conditions can also enable the formation and potentially recovery of monomers and high-value chemicals from the gasification of agricultural residues (Table 2). Near the critical temperature, catalysts are required and a gas containing $\mathrm{CH}_{4}$ is generated. At critical and higher temperatures, the generated gas will be rich in hydrogen if the concentration of the agricultural wastes feedstock is low and if the concentration of the biomass in water does not decrease. At these conditions, the product tends to contain more hydrocarbons and become less amenable for biomass conversion (Yusman, 2007).

Composition of the feed plays a role in $\mathrm{H}_{2}$ yields through gasification. Safari et al. (2016) found that wheat straw yielded more $\mathrm{H}_{2}$ than walnut or almond shell on account of its high lignin content; the corresponding $\mathrm{H}_{2}$ yields from wheat straw, almond shell and walnut were $7.25,4.10$, and $4.63 \mathrm{mmol} \mathrm{g}^{-1}$ at 10, 15, and 20 mins, respectively. Yoshida et al. (2009) pre-treated sewage
Table 2.

Selected agricultural waste biomass used to generate biofuel(s) under supercritical water gasification conditions.

\begin{tabular}{|c|c|c|c|}
\hline Feedstocks & Temperature $\left({ }^{\circ} \mathrm{C}\right)$ & Pressure (MPa) & Reference \\
\hline $\begin{array}{l}\text { Corn starch, Potato } \\
\text { starch and waste }\end{array}$ & 600 & $22-34.5$ & Peterson et al. (2008) \\
\hline Oily waste water & $500-650$ & $25-41$ & Zhiyong and Xiuyi (2015) \\
\hline Timothy grass & $450-650$ & $23-25$ & Nanda et al. (2016a) \\
\hline Eucalyptus grandis & 450 & 27 & Louw et al. (2016) \\
\hline Rice straw & Less than 600 & 25 & Yoshida et al. (2004) \\
\hline Beet residues & $450-600$ & 30 & Ondze et al. (2015) \\
\hline Peanut shell & $600-800$ & 25 & Lu et al. (2007) \\
\hline Corn cob & $600-800$ & 25 & Lu et al. (2007) \\
\hline Fruit pulp & $400-600$ & 25 & Elif and Nezihe (2016) \\
\hline Chicken manure & 620 & 30 & Cao et al. (2016) \\
\hline Sugarcane bagasse & 400 & - & Barati et al. (2014) \\
\hline Sewage sludge & $400-600$ & $24.6-49.6$ & Acelas et al. (2014) \\
\hline Wheat straw & 650 & 26 & Kang et al. (2016c) \\
\hline $\begin{array}{l}\text { Empty fruit bunches } \\
\text { of oil palm }\end{array}$ & 380 & 24 & Sivasangar et al. (2015) \\
\hline Sewage sludge & 600 & 23 & Sawai et al. (2014) \\
\hline Food waste & 400 & 22.1 & $\begin{array}{l}\text { Amuzu-Sefordzi et al. } \\
(2014)\end{array}$ \\
\hline
\end{tabular}

sludge using sub-critical water hydrolysis and reported a two-fold increase in methane yield (after $3 \mathrm{~d}$ incubation) for the pre-treated sludge.

Table 3 tabulates studies on supercritical water gasification of model compounds for biogas production in recent years. Reddy et al. (2014) investigated the decomposition routes of cellulose and lignin under quasi-supercritical conditions and found that temperature, pressure, reaction time, catalysts, feed concentration, and reactor configuration all influenced $\mathrm{H}_{2}$ production. These authors also indicated that around supercritical temperatures and pressures, hydrolysis rates could be enhanced based on ionic mechanisms and if reactors used for supercritical water gasification still had much scope for optimization. Demirbas (2010) found the generation of hydrogen under supercritical gasification with water highly attractive, although its cost of production was greater that hydrogen production from steam methane reforming. In this same work, increasing the temperature from $600-800^{\circ} \mathrm{C}$ at residence times of 2-6 s increased the $\mathrm{H}_{2}$ yield from 53 to $73 \%$ by volume, while the effect of pressure was negligible beyond the critical pressure of water. Guo et al. (2012) investigated hydrogen evolution from supercritical water gasification of glycerol at $445-600^{\circ} \mathrm{C}, 25 \mathrm{MPa}$, and 3.9-9.0 s in continuous flow, and indicated that increasing the temperature greater than $487^{\circ} \mathrm{C}$ and/or increasing the glycerol concentration in the feed improved the gasification efficiency.

Supercritical biomass gasification can benefit from innovative reactor engineering approaches. Liao et al. (2013) studied supercritical water gasification of glucose and corncob using a novel solar thermal reactor. In this work, an increase in direct normal solar irradiation (DNI) caused an increase in the reactor temperature. Moreover, the elevated DNI and low feed concentrations increased $\mathrm{H}_{2}$ yield, indicating the effectiveness of solar energy in supercritical water gasification systems. Later, Onwudili and Williams (2013) evaluated the potential of pre-treating sawdust using subcritical water prior to supercritical water gasification and reported an increase in gas yields from $24.6 \mathrm{~mol} \mathrm{~kg}^{-1}$ for untreated sawdust to $47.7 \mathrm{~mol}$ $\mathrm{kg}^{-1}$ for pre-treated sawdust (neutral conditions). 
Table 3.

Summary of supercritical water gasification of model compounds for biogas production.

\begin{tabular}{|c|c|c|c|c|}
\hline Model compounds & Catalyst & Experimental condition & Experimental results & Reference \\
\hline Glucose & $\begin{array}{l}\text { Homogeneous } \\
\text { organometallic catalyst and } \\
\text { Raney nickel }\end{array}$ & $\begin{array}{l}\text { Temperature: } 310-350^{\circ} \mathrm{C} \text { Pressure: } 10- \\
21 \mathrm{MPa}\end{array}$ & $\begin{array}{l}\text { homogeneous } \\
\text { catalysts less effective than Raney nickel }\end{array}$ & Azadi et al. (2009) \\
\hline Cellulose & $\begin{array}{l}\mathrm{Ru} / \mathrm{C}, \mathrm{Pd} / \mathrm{C}, \mathrm{CeO}_{2} \text { particles, } \\
\text { nano- } \mathrm{CeO}_{2} \text {, nano-(CeZr)xO }\end{array}$ & Temperature: $500{ }^{\circ} \mathrm{C}$ Pressure: $27 \mathrm{MPa}$ & $\begin{array}{l}\text { Catalyst used was } \mathrm{Ru} / \mathrm{C}_{4} \mathrm{Pd} / \mathrm{C}_{4} \text { nano- } \\
(\mathrm{CeZr}) \mathrm{xO}_{24} \text { nano- } \mathrm{CeO}_{24} \mathrm{CeO}_{2} \text { particles. With } \\
\text { sodium carboxymethylcellulose, cellulose or } \\
\text { sawdust can be completely gasified }\end{array}$ & Hao et al. (2005) \\
\hline Xylan (Hemicellulose) & $\mathrm{Ru} / \mathrm{a}-\mathrm{Al}_{2} \mathrm{O}_{3} / \mathrm{CaO}$ & Temperature: $550{ }^{\circ} \mathrm{C}$ Pressure: $36 \mathrm{MPa}$ & Hydrogen yield was of $10.7 \mathrm{~mol} \mathrm{~kg}^{-1}$ & Onwudili and Williams (2013) \\
\hline Glycerol & $\mathrm{Ru} / \mathrm{Al}_{2} \mathrm{O}_{3}$ & Temperature: $700-800{ }^{\circ} \mathrm{C}$ & $\begin{array}{l}\text { Ruthenium had high activity for } \mathrm{C}-\mathrm{C} \text { bond } \\
\text { cleavage; } \mathrm{H}_{2} \text { synthesis decreased when } \mathrm{CH}_{4} \\
\text { increased when glycerol levels were augmented } \\
\text { to } 40 \% \text {. }\end{array}$ & Byrd et al. (2008) \\
\hline Humic acid & - & $\begin{array}{l}\text { Temperatures: } 325-600{ }^{\circ} \mathrm{C} \text { Feed } \\
\text { concentration: } 10-25 \mathrm{wt} . \% \\
\text { Reaction time: } 30-90 \mathrm{~min}\end{array}$ & $\begin{array}{l}\text { High } \mathrm{H}_{2} \text { yield of } 0.79 \mathrm{~mol} \mathrm{~kg}^{-1} \text { at } 600{ }^{\circ} \mathrm{C}, 15 \\
\text { wt.\% humic acid and } 75 \mathrm{~min} \text { without catalyst. }\end{array}$ & Gong et al. (2017) \\
\hline Phenols & $\mathrm{Ru} / \mathrm{CeO}_{2}$ & $\begin{array}{l}\text { Temperatures: } 450-500^{\circ} \mathrm{C} \\
\text { Feed concentration: } 5 \text { wt. } \% \text { phenol }\end{array}$ & $\begin{array}{l}\text { Carbon utilization efficiency rose to } 90 \% \text { in } \\
\text { supercritical water gasification of phenol with } \\
\mathrm{Ru} / \mathrm{CeO}_{2} \text { and } 5 \text { wt. } \% \text { loading of phenol Gaseous } \\
\text { yields had risen from } 60 \% \text { (no catalysis) } 150 \% \text { at } \\
500{ }^{\circ} \mathrm{C} \text { with catalyst. }\end{array}$ & Guan et al. (2016) \\
\hline Methanol & Ni catalyst & $\begin{array}{l}\text { Temperature: } 500-550{ }^{\circ} \mathrm{C} \\
\text { Feed concentration: } 10 \mathrm{wt} . \% \text { methanol }\end{array}$ & $\begin{array}{l}\text { Conversion rates significantly enhanced with } \mathrm{Ni} \\
\text { catalyst. }\end{array}$ & DiLeo and Savage (2006) \\
\hline Oleic acid & $\begin{array}{l}\mathrm{Ru} / \mathrm{Al}_{2} \mathrm{O}_{3}, \mathrm{Ru} / \mathrm{AC}, \mathrm{Pt} / \mathrm{AC} \\
\mathrm{Pd} / \mathrm{AC}, \mathrm{Ni} / \mathrm{SiO}_{2}-\mathrm{Al}_{2} \mathrm{O}_{3}\end{array}$ & $\begin{array}{l}\text { Temperature: } 400-500{ }^{\circ} \mathrm{C} \text {, Pressure: } 28 \\
\text { MPa } \\
\text { Reaction time: } 30 \mathrm{~min}\end{array}$ & $\begin{array}{l}\text { Higher temperatures and catalyst considerably } \\
\text { improved yields. }\end{array}$ & Youssef et al. (2011) \\
\hline Lignin & $\mathrm{Ni} / \mathrm{MgO}$ & Temperature: $250-400^{\circ} \mathrm{C}$, & $\begin{array}{l}\text { Higher nickel loadings on magnesium oxide } \\
\text { augmented synthesis of gases. Highest yield was } \\
78 \% \text { with } 20 \mathrm{wt} . \% \mathrm{Ni} / \mathrm{MgO} \text { catalyst }\left(400^{\circ} \mathrm{C}\right) \text {. }\end{array}$ & Sato et al. (2006) \\
\hline Cellulose and lignin alkali & $\begin{array}{l}\text { alkali catalyst }\left(\mathrm{K}_{2} \mathrm{CO}_{3}\right) \text { and } \\
\text { absence of catalyst }\end{array}$ & $\begin{array}{l}\text { Temperature: } 300-600{ }^{\circ} \mathrm{C} \\
\text { Pressure: } 9-41 \mathrm{MPa} \\
\text { Reaction time } 1 \mathrm{~h}\end{array}$ & $\begin{array}{l}\mathrm{K}_{2} \mathrm{CO}_{3} \text { favored gasification rates and restricted } \\
\text { char generation. }\end{array}$ & $\begin{array}{l}\text { Güngören Madenoğlu et al. } \\
\text { (2016) }\end{array}$ \\
\hline Fructose & $\mathrm{KOH}$ and $\mathrm{NaOH}$ catalyst & $\begin{array}{l}\text { Temperature: } 550-700{ }^{\circ} \mathrm{C} \\
\text { Residence time: } 30-75 \mathrm{~s} \\
\text { Feed concentration: } 4-10 \% \\
\text { Catalyst concentration: } 0,2-0,8 \% \\
\text { Pressure: } 25 \mathrm{MPa}\end{array}$ & $\begin{array}{l}\text { Gas synthesis yields, carbon gasification } \\
\text { efficiency and hydrogen yields much improved } \\
\text { at optimum conditions }\left(700{ }^{\circ} \mathrm{C}, 60 \mathrm{~s} \text { residence }\right. \\
\text { feed concentration of } 4 \mathrm{wt} . \%) \text {. }\end{array}$ & Nanda et al. (2015) \\
\hline Glucose & - & $\begin{array}{l}\text { Temperature: } 550{ }^{\circ} \mathrm{C} \\
\text { Pressure: } 25 \mathrm{MPa} \\
\text { Flow rate water: } 1-10 \mathrm{~mL} / \mathrm{min} \\
\text { Conc. Solution: } 50,100,150,250 \mathrm{~g} / \mathrm{L}\end{array}$ & $\begin{array}{l}\text { Biogas generation fluctuated from } 100-200 \mathrm{~L} \mathrm{~kg}^{-1} \\
\text { glucose Biogas composition (vol./vol.) was: CO } \\
40-50 \%, \mathrm{H}_{2} 10-15 \%, \mathrm{CH}_{4} 10-20 \%, \mathrm{C}_{2+} 2-8 \% \text {, } \\
\text { with finally } \mathrm{CO}_{2} 20-30 \% \text {. }\end{array}$ & Molino et al. (2016) \\
\hline
\end{tabular}

The role of catalysis has also been regularly studied in biomass processing for biofuel production under subcritical and supercritical conditions using different liquids (namely ethanol, methanol, and water). Although the exact mechanistic pathways involved remain unclear, many studies have shown that the overall process performance and yield were enhanced when using specific types of metal-based (Azadi and Farnood, 2011) and/or zeolite-type catalysts (Fig.2), while only a few studies have demonstrated that adequately satisfactory process metrics could be reached in catalyst-free reactions. Guo et al. (2010) provided an overview on the physicochemical characteristics of supercritical water gasification and confirmed that alkali metal catalysts enhance water-gas-shift reactions, but cause fouling and corrosion of equipment. Again according to Guo et al. (2010), transition metal catalysts promote methanation reactions, catalyze steam reforming reactions, and bond breakage. Yet, many catalysts are instable followed by damages of their support.

Process conditions influence gasification efficiency and $\mathrm{H}_{2}$ yields. Kang et al. (2016a) conducted a process optimization study on the catalytic gasification of lignin and cellulose under supercritical condition with water using $\mathrm{K}_{2} \mathrm{CO}_{3}$ and $20 \mathrm{Ni}-0.36 \mathrm{Ce} / \mathrm{Al}_{2} \mathrm{O}_{3}$ through Taguchi experimental design for process optimization. They found that temperature exerted the highest impact on the process followed by catalyst type and loading, and finally the type of biomass used. They also found that $\mathrm{H}_{2}$ yield was enhanced at the high temperatures of $650^{\circ} \mathrm{C}$ and high catalyst loading. Nanda et al. (2016b) probed the influence of nickel-laden feedstocks gasified in sub- and supercritical water conditions at varying temperatures, water-to-biomass ratios, pressures, and residence times, and thence found that nickel-laden biomasses yielded more hydrogen that non-catalytic ones with the optimal conditions for gasification observed at $500^{\circ} \mathrm{C}$, a water-to-biomass ratio of 10 at $45 \mathrm{~min}$ and 23-25 MPa. Susanti et al. (2012) assessed supercritical water gasification of glucose in an updraft gasifier reactor under different temperatures, reaction time, feed concentration, and without a catalyst, and showed that the total gas and hydrogen yields increased with increasing temperatures. Moreover, the highest yields were achieved at $740^{\circ} \mathrm{C}$ and 1.8 wt. \% of feed for $60 \mathrm{~s}$, and carbon efficiency of $91 \%$ was recorded.

Catalysts enhance $\mathrm{H}_{2}$ yields by favoring the reactions of the water gas shift process according to Parthasarathy and Narayanan (2014). Seif et al. (2016) studied the hydrothermal gasification of various industrial waste streams using different catalysts, temperatures and reaction times, and reported that $\mathrm{Co}_{3} \mathrm{O}_{4}$ was the most effective catalyst that could enhance the gasification efficiency and $\mathrm{H}_{2}$ yields. Seif et al. (2016) also argued that 


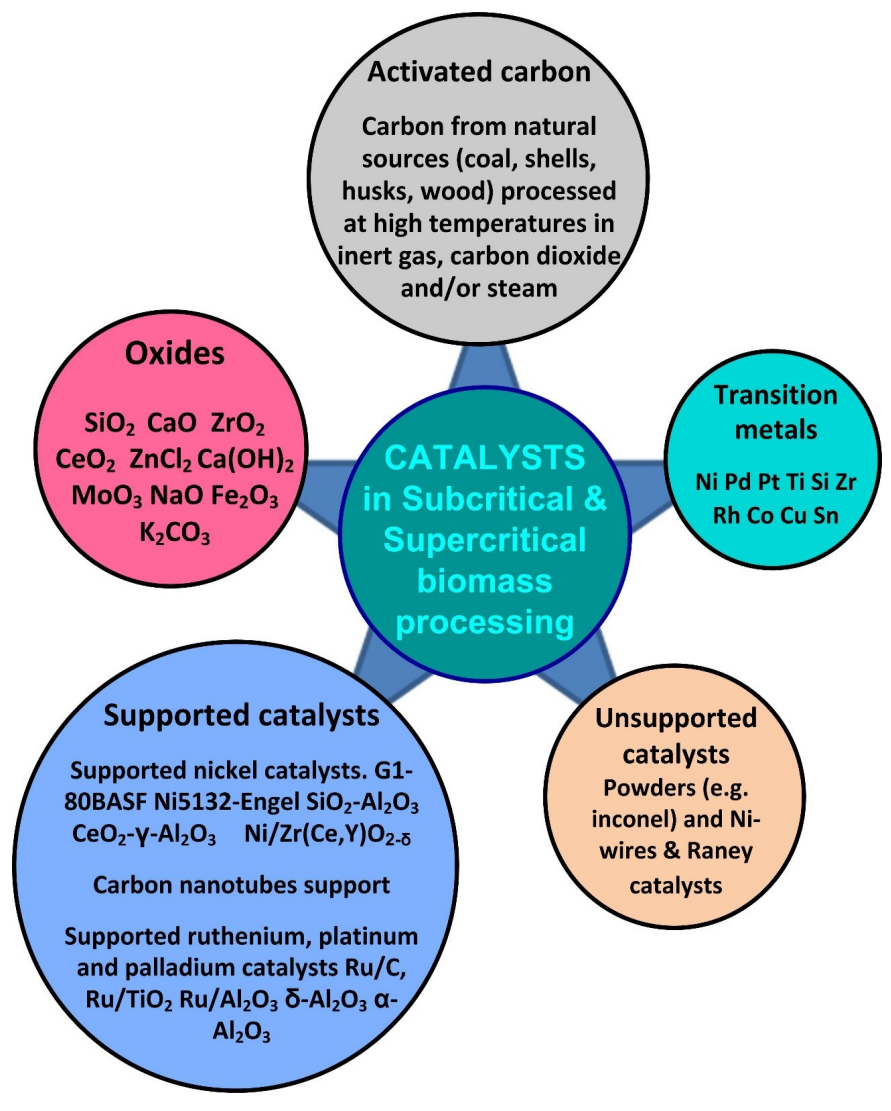

Fig.2. Broad classification of the main types of homogeneous and heterogeneous catalysts used in biomass processing for biofuel production under subcritical and supercritical conditions.

temperatures over $375^{\circ} \mathrm{C}$ and residence time of 45 min promoted $\mathrm{H}_{2}$ generation, although catalysts were more effective at lower temperatures and longer residence time.

Gasification of fruit pulp in supercritical water catalyzed by $\mathrm{Ru} / \mathrm{C}$ was investigated at varying temperatures, residence times, as well as biomass and catalyst ratios by Elif and Nezihe (2016), who demonstrated that $\mathrm{H}_{2}$ yield increased by $400 \%$ at temperatures greater than $500^{\circ} \mathrm{C}$. Huang et al. (2017) studied the catalytic supercritical water gasification of glucose over $\mathrm{Ni} / \mathrm{Zr}(\mathrm{Ce}, \mathrm{Y}) \mathrm{O}_{2}-\delta$ catalysts at $500^{\circ} \mathrm{C}, 23-24 \mathrm{MPa}$, and feed concentration of 10 wt. $\%$, and reported that carbon gasification efficiency was improved as $\mathrm{Ni}$ concentration was increased from 0.1 to 0.7 . In this same work, a hydrogen yield of $22 \mathrm{~mol} \mathrm{~kg}{ }^{-1}$ was obtained using $\mathrm{Ni}_{0.5} \mathrm{Zr}_{0.8} \mathrm{Y}_{0.2} \mathrm{O}_{2.8}$ (NZY582) catalyst which was 10 times greater than that of the catalyst-free conditions. Addition of $\mathrm{Ni} / \mathrm{CeO}_{2}-\gamma \mathrm{Al}_{2} \mathrm{O}_{3}$ catalyst to supercritical water gasification of biomass at $400^{\circ} \mathrm{C}, 24.5 \mathrm{MPa}$, and 9.09 wt.\% glucose greatly boosted $\mathrm{H}_{2}$ yield and selectivity according to Lu et al. (2010). They also deduced that coking and carbon deposits caused deactivation of catalysts and the presence of $\mathrm{Ce}$ in the catalysts inhibited this phenomenon.

Catalyst selection is also an important consideration, both in terms of activity and stability. Yamaguchi et al. (2009) investigated the generation of hydrogen under supercritical water gasification regimes of woody biomass with catalyst and observed that $\mathrm{H}_{2}$ yield was heightened at shorter residence time and elevated temperatures. Palladium > ruthenium > platinum > rhodium > nickel catalysts over activated carbon and titanium favored lignin gasification. Amuzu-Sefordzi et al. (2014) demonstrated that nickel catalysts promoted steam reforming reactions (at $400^{\circ} \mathrm{C}$ and $22.1 \mathrm{MPa}$ for $10 \mathrm{~min}$ ) with minimum impacts on the water gas shift reaction compared with alkali catalysts $(\mathrm{NaOH})$, which favored $\mathrm{H}_{2}$ yield. Behnia et al. (2016) probed the influence of nickel and ruthenium metallic catalysts on $\mathrm{CH}_{4}$ and $\mathrm{H}_{2}$ generation from glucose subjected to supercritical water gasification at $500^{\circ} \mathrm{C}$ and reported the greatest $\mathrm{H}_{2}$ yields and complete carbon conversion in glucose were achieved using Ni20\%
$\mathrm{Ru} 2 \% / \gamma-\mathrm{Al}_{2} \mathrm{O}_{3}$ catalyst. Tar formation was inhibited and $\mathrm{CH}_{4}$ formation was improved. Kang et al. (2016b) screened of 29 catalysts generated using 5 supports for the production of hydrogen by the water gasification of lignin under supercritical conditions, and finally ranked Ni-based catalysts in order of reactivity as follows: $\mathrm{Al}_{2} \mathrm{O}_{3}>\mathrm{TiO}_{2}>\mathrm{AC}>\mathrm{ZrO}_{2}>\mathrm{MgO}$. Kang et al. (2016b) also showed that $\mathrm{Ce}$ improved $\mathrm{H}_{2}$ selectivity by favoring dispersion of $\mathrm{Ni}$ and inhibiting $\mathrm{Ni}-\mathrm{Al}_{2} \mathrm{O}_{3}$ interactions. In their study, the $20 \mathrm{Ni}-0.36 \mathrm{Ce} / \mathrm{Al}_{2} \mathrm{O}_{3}$ catalyst exhibited a peak $\mathrm{H}_{2}$ yield of $2.15 \mathrm{mmol} \mathrm{g}{ }^{-1}$. Li et al. (2011) observed that $\mathrm{Cu}$ improved the catalytic performance of $\mathrm{Ni}$ in reforming reactions to generate $\mathrm{H}_{2}$, and that $\mathrm{Cu}$ also mitigated sintering of alumina whilst Co promoted $\mathrm{Ni}$-based catalysis with respect to hydrogen selectivity. Madenoğlu et al. (2012) studied the sub- and supercritical gasification behavior of cotton and tobacco stalks with water as supercritical fluid at $300-600^{\circ} \mathrm{C}$ with addition of $10 \mathrm{wt} . \%$ of natural mineral catalysts, and found that Trona was most effective while Dolomite was least efficient. They claimed $\mathrm{H}_{2}$ yields as high as $42.9 \%$ and $39.9 \%$ from tobacco and cotton stalks using Trona as catalyst at $600^{\circ} \mathrm{C}$, respectively. The generation of hydrogen using subcritical water gasification of food wastes, glucose, and glutamic acid was studied by Muangrat et al. (2010) who examined the effects of adding $\mathrm{NaOH}, \mathrm{Ni} / \mathrm{Al}_{2} \mathrm{O}_{3}$, and $\mathrm{Ni} / \mathrm{SiO}_{2}$ catalysts. They found that glutamic acid yielded less hydrogen than glucose and the addition of $\mathrm{NaOH}$ increased $\mathrm{H}_{2}$ production while the combined use of the different catalyst with $\mathrm{NaOH}$ resulted in a marginal increase in $\mathrm{H}_{2}$ yield. An interesting feature of the work of Muangrat et al. (2010) was that $\mathrm{NaOH}$ was capable of preventing carbon deposition on the active sites of the catalysts.

\section{Hydrothermal carbonization}

\subsection{Hydrothermal reaction mechanism}

HTC comprises a complex network of reactions, and kinetics and details of each reaction are governed by feedstock, temperature, and pressure. A large number of chemical reactions occur during biomass conversion to hydrothermal char, and the full reaction network is not yet established. However, the conversion of biomass to biochar is believed to involve parallel and sequential hydrolysis, dehydration, condensation, and polymerization reactions (Funke and Ziegler, 2010). For example, Brunner (2009) suggested that the network consists of hydrolysis of glycosidic bonds to convert biomass polymers into sugars, followed by hydrolytic degradation of the simple sugars to produce compounds that act as building blocks to form hydrothermal chars. Similarly, Titirici et al. (2008) found that hexoses like glucose react to form HMF as an intermediate, while pentoses like xylose instead form furfural. Subsequent to biopolymer breakdown, the resulting simple carbohydrates and degradation products condense to form larger molecules (Titirici et al., 2007). Aromatization reactions convert the carbohydrate and furanic molecules into fully and partially aromatic structures in the hydrothermal char (Baccile et al., 2009 Sevilla and Fuertes, 2009a). Falco et al. (2011) reported that the aromaticity of the product char depends on the molecular structure of the carbohydrate feed; for example, xylose carbonization results in a more arenic product than does glucose carbonization. Throughout the process, decarboxylation and decarbonylation reactions remove carbonyl groups from the hydrothermal char, resulting in the production of $\mathrm{CO}_{2}$ and $\mathrm{CO}$ while reducing the oxygen content of the hydrothermal char ( $\mathrm{Li}$ et al., 2011). Timko et al. (2016b) reported a ball milling treatment that simultaneously decreased the oxygen content of a hydrothermal char and increased its aromaticity. The authors attributed their finding to the formation and recombination of carbon radicals during ball milling.

\subsection{Hydrothermal carbonization process}

Valorization of solid byproducts formed during gasification or hydrolysis of biomass feeds is key for improving overall process economics and maximizing environmental benefits of using bio-renewable feeds. In fact, the solids themselves may have sufficient value to justify HTC as a stand-alone process and in recent years the technology has been the subject of several reviews (Funke and Ziegler, 2010; Titirici and Antonietti, 2010; Libra et al., 2011). As a thermal process which is conducted in the presence of a liquid water phase, HTC offers a favorable energy balance compared 
with pyrolysis or torrefaction for wet feeds. Moreover, the performance of the HTC process can be tuned by adjusting many operating parameters including: the design of the reactor, the reaction thermal history (including the set point temperature, ramp rate, and cooling rate), pressure, time, and the feedstock itself.

In terms of reactor designs, HTC is usually performed in sealed batch reactors, with only a limited number of studies reported HTC under flow conditions (Elliott et al., 2013; Jazrawi et al., 2013). Large-scale batch HTC reactors have been reportedly built at industrial scale while design and operation of flow reactors are on-going topics of university and industrial research. In terms of pressure, most HTC processes are performed at the saturation pressure of water, though several studies have measured the pressure changes that occur during the HTC process (Heilmann et al., 2010). The effects of operating HTC at pressures greater than the saturation pressure of water are unknown, but are likely modest given the body of work on HTL.

Hydrothermal carbonization is typically performed at temperatures ranging from 150 to $300^{\circ} \mathrm{C}$, as these temperatures maximize the char yield (Sevilla and Fuertes, 2009b). Reaction temperatures must be selected to optimize the overall energy balance (Funke et al., 2013) as well as to tune the char yield and/or composition. Gao et al. (2012) and Sevilla and Fuertes (2009a) showed that properties, such as particle size and yield of the hydrothermal char product are dependent on the reaction temperature. Furthermore, using nuclear magnetic resonance (NMR) spectroscopy, Falco et al. (2011) reported that increasing reaction temperature of hydrothermal carbonization increased the arene content relative to furan of the hydrothermal chars and decreased the carbonyl content in the same char (Falco et al., 2011).

Reaction time has been reported to have a small effect on the yield of hydrothermal char (Sevilla and Fuertes, 2009a; Sevilla and Fuertes, 2009b). However, the composition and properties of the material has been found to vary with time. Gao et al. (2012) examined the effect of residence time on the properties of hydrothermal chars made from water hyacinth, reporting that the oxygen content decreased from $20 \mathrm{wt} . \%$ to $13 \mathrm{wt} . \%$ after $4 \mathrm{~h}$ of reaction time. Thermal analysis indicated that chars recovered after 6 and $24 \mathrm{~h}$ of reaction time showed nearly identical derivative thermograms (DTG) graphs (Gao et al., 2012). Similarly, Falco et al. (2011) used NMR analysis and showed that the structure of hydrothermal char changed rapidly over the first several hours of reaction, and then stayed mostly constant.

As mentioned previously, HTC is suited to processing a wide range of wet and dry biomass feedstocks, including agricultural waste biomass (Sevilla et al., 2011; Xue et al., 2012) and municipal wastewater sludge (Berge et al., 2011). Wiedner et al. (2013) reported that carbonization of different whole biomass feedstocks produced hydrothermal chars with different properties; however, establishing a predictive link between hydrothermal char composition and the composition of the feed is a current knowledge gap (Kang et al., 2012). Despite the challenge, progress is being made to tailor char composition. For example, Demir-Cakan et al. (2009) co-carbonized glucose and acrylic acid to produce hydrothermal char enriched in carboxylic acids. Latham et al. (2014) used a nitrogen-enriched algal feed solution to produce a nitrogen-rich char. Likewise, Yang et al. (2012) carbonized chitosan, a acetyl functionalized polymer of d-glucosamine, to obtain a nitrogen-rich material that was easily made highly fluorescent (Zhao and $\mathrm{Wu}, 2006$ ).

\subsection{Hydrothermal char characterization}

The variety of feedstocks and reaction conditions make hydrothermal carbonization a highly variable process, the result of which is a complex, heterogeneous molecule. Figure 3 shows three hydrochar model compounds proposed by Sevilla and Fuertes (2009a), Chuntanapum and Matsumura (2009), and Latham et al. (2017). Many different techniques have been deployed in attempts to better understand the structure and properties of hydrothermal char. Most commonly elemental analysis has been used to understand how it compares to more common thermal residues, such as pyrolysis char or soot. Hydrothermal chars generally show higher carbon contents and lower oxygen contents than their corresponding feeds (Sevilla and Fuertes, 2009a; Sevilla and Fuertes, 2009b), but also tend to have higher oxygen contents than pyrolysis chars (Bridgwater et al., 1999).

Vibrational spectroscopy, both infrared and Raman, is often used to characterize hydrothermal chars. Infrared spectroscopy indicates that the hydrothermal char surface consists of many different oxygen-bearing functional groups (Sevilla and Fuertes, 2009a; Liu et al., 2013). Because of

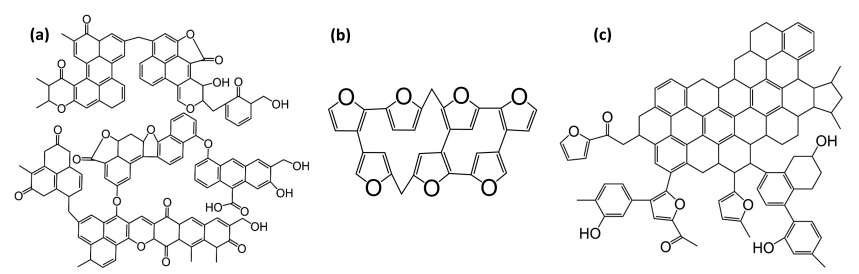

Fig.3. Hydrothermal char model compounds proposed in the literature. Molecular structures (a), (b), and (c) given here are redrawn based on the data from the following sources: Structure (a) is reprinted (adapted) with permission from Sevilla and Fuertes (2009a) Copyright $\odot$ 2009; WILEY-VCH Verlag GmbH \& Co. KGaA, Weinheim [License number: 4061700558451]; Structure (b) is reprinted (adapted) with permission from Falco et al (2011). Copyright $\odot$ 2011; American Chemical Society; and Structure (c) is reprinted (adapted) with permission from Chuntanapum and Matsumura (2009). Copyright@ 2009, American Chemical Society.

apparent similarities with the spectra of graphitic materials (Sadezky et al., 2005; Ferrari et al., 2006; Graf et al., 2007), Raman micro-spectroscopy of hydrothermal char suggests a defect-rich carbonaceous structure, consisting of polycyclic aromatic hydrocarbon (PAH) sub-units with 8-10 rings (Chuntanapum and Matsumura, 2009). However, Raman spectra of furan and furan-derived molecules (Kim et al., 2011) suggest that interpretation of hydrothermal char spectra may not be straightforward and that the presence of oxygen functional groups may shift band locations and intensities. Efforts to improve the interpretation of hydrothermal char Raman spectra are underway and may follow similar work performed for analysis of pyrolysis chars (Smith et al., 2016). In contrast with Raman micro-spectroscopy, NMR spectroscopy suggests that hydrothermal char is a highly furanic material (Baccile et al., 2009), consisting of PAH sub-units possessing approximately 1-5 rings on average. Carbon X-ray Absorption Near Edge Spectroscopy (C-XANES) spectra of hydrothermal char are also consistent with those of a furanic material, consisting of small PAH subunits (Latham et al., 2017).

\subsection{Hydrothermal char applications}

As previously stated, hydrothermal chars are being investigated for a variety of applications that benefit from high surface areas (which can be achieved by post-reaction activation), high oxygen content of the hydrothermal char surface, or the ability of hydrothermal chars to be modified to include various heteroatoms or functional groups (e.g., carboxylic acids, amines, and sulfonic acids) (Fig. 4). Reported surface areas of hydrothermal chars range from approximately $10 \mathrm{~m}^{2} \mathrm{~g}^{-1}$ for chars synthesized from simple carbohydrates up to approximately $100 \mathrm{~m}^{2} \mathrm{~g}^{-1}$ for some biomass-derived chars (Sevilla and Fuertes, 2009a; Liu et al., 2010). Base treatments can increase the measured surface area of hydrothermal chars. For example, Li et al. (2011) and Sevilla et al. (2011) pyrolyzed a hydrothermal char in the presence of $\mathrm{KOH}$ to increase the surface area of the hydrothermal char from approximately $10 \mathrm{~m}^{2} \mathrm{~g}^{-1}$ to greater than 1200 $\mathrm{m}^{2} \mathrm{~g}^{-1}$. The increased surface area obtained after base treatment may be due to removal of acidic side chains that would block pore access ( $\mathrm{Li}$ et al., 2011), as well as partial gasification and expansion of lattice structure of the aromatic islands that would form as a result of temperature treatment (Yoon et al., 2004). These increased surface areas were used by Sevilla et al. (2011) to produce high capacitance carbon electrodes with a specific capacitance of $236 \mathrm{~F} \mathrm{~g}^{-1}\left(100 \mathrm{~F} \mathrm{~cm}^{-3}\right)$ measured at a sweep rate of $1 \mathrm{mV} \mathrm{s}$ 1. Sevilla et al. (2011) also showed that that these high surface area materials (Li et al., 2011) could be used for hydrogen storage; in fact, the 5 wt.\% hydrogen storage capacity of hydrothermal char was very similar to the reported hydrogen capacity of carbon nanotubes (Cheng et al., 2001).

Given the success of pyrolysis chars for soil amendment and remediation applications (Sohi et al., 2010), soil amendment is an obvious application for hydrothermal chars. However, the behavior of hydrochars and pyrolysis chars are distinct from one another, and the two materials cannot be used interchangeably. For example, Eibisch et al. (2015) reported that pyrolysis char reduced the in situ availability of a model pesticide (isoproturon) by a 

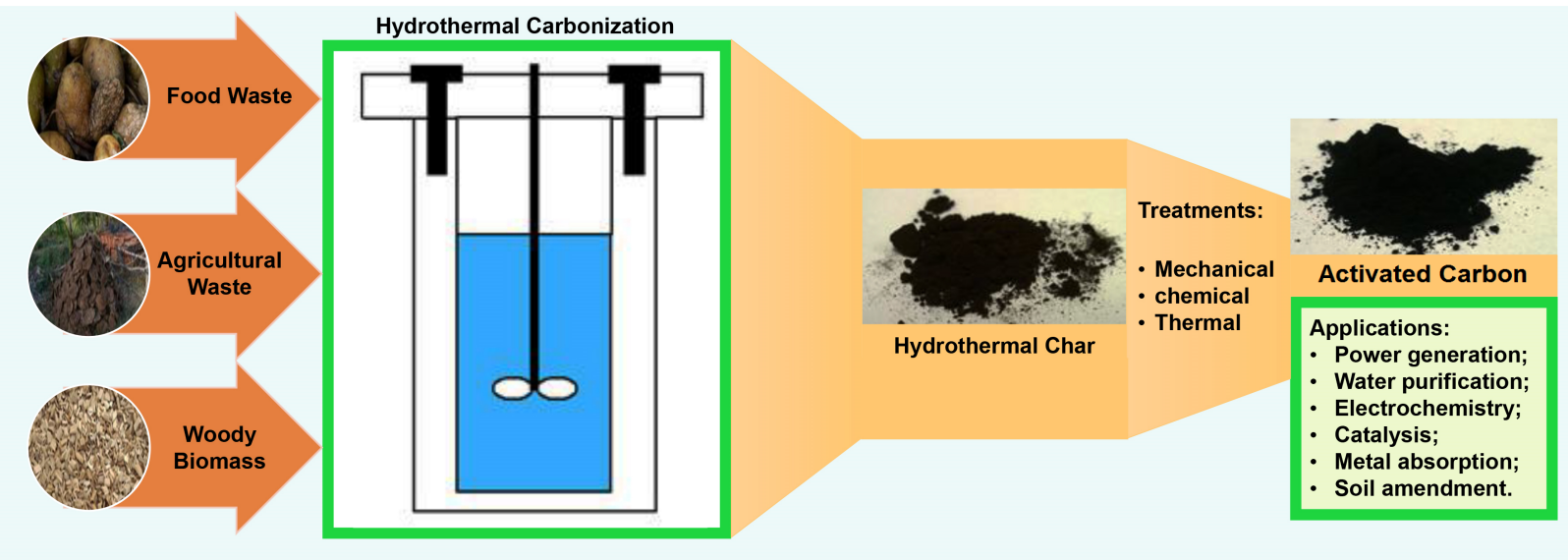

Fig.4. Hydrothermal char applications from agricultural waste, woody biomass and food waste.

factor of 10-2283 compared with 3-13 observed for hydrothermal char treatments. On the other hand, Ro et al. (2016) reported that the nutrient retention of hydrothermal char-amended soils was greater than what observed for pyrolysis char-amended soils, though the mechanism of nutrient retention could not be clarified. Malghani et al. (2013) showed that hydrothermal chars are less stable than pyrolysis chars in soil, as the carbon content of soils mixed with hydrothermal chars decreased by $60 \%$ after $105 \mathrm{~d}$, while the carbon content reduction of soils mixed with pyrolysis chars was only $10 \%$. Moreover, Busch et al. (2012) reported potential toxicity concerns with using hydrothermal char in soils, potentially a consequence of using raw hydrothermal chars that were not rinsed prior to use.

Hydrothermal chars have shown promises for adsorption of metal cations from aqueous solutions. Regmi et al. (2012) reported that the copper and cadmium adsorption capacities of switchgrass hydrothermal chars were comparable to those measured for Calgon WPH® activated carbon. Furthermore, an aqueous $\mathrm{KOH}$ post-treatment increased adsorption capacity by nearly 100\% (Regmi et al., 2012). Similarly, Demir-Cakan et al. (2009) showed that hydrothermal chars co-carbonized with acrylic acid produced materials with lead and cadmium high capacities (approximately $350 \mathrm{mg} \mathrm{g}^{-1}$ for lead and $988 \mathrm{mg} \mathrm{g}^{-1}$ for cadmium). These extremely high adsorption capacities compared favorably with that measured for $\mathrm{HNO}_{3}$ oxidized carbon nanotubes; the lead and cadmium capacities of oxidized nanotubes have been reported as 97 and $10.9 \mathrm{mg} \mathrm{g}^{-1}$, respectively. Xue et al. (2012) found that $\mathrm{H}_{2} \mathrm{O}_{2}$ treatment increased the lead adsorption capacity of a peanut shell hydrothermal char from $0.88 \mathrm{mg} \mathrm{g}^{-1}$ to $22.82 \mathrm{mg} \mathrm{g}^{-1}$, a performance similar to that of an activated carbon.

\section{Conclusions}

Renewable energy is an area of active research which includes solar energy, wind power systems, geothermal power, and bioenergy. Renewable energy derived from biomass processing systems holds substantial promises and prospects for scale-up towards mass production of different types of bioenergy, namely, bio-ethanol and other liquid fuels, biogas, (or biohydrogen, biomethane, or biohythane), and hydrothermal chars. However, utilization of a renewable resource does not ensure an environmentally-sustainable process. For this reason, the principles of green chemistry and green engineering must be coupled with the utilization of renewable resources to yield environmentally-sustainable production of bioenergy. The application of subcritical and/or supercritical conditions for water extraction, water hydrolysis, water and hydrothermal carbonization using a variety of biomass embodies many principles of green chemical engineering. The core of green engineering principles encompassed by subcritical and/or supercritical processing for bioenergy generation is designing less hazardous and low-toxic chemical synthetic routes which may additionally be catalytically assisted and use benign/safer solvents. Moreover, these chemical schemes are intended to be more energy efficient using renewable feedstocks.
The present review also highlights three main areas of research. The first area is related to the significant impact and influence of the process fluid temperature(s) on the kinetics of the processes and on the thermal stability of the moieties involved. Conversely, the impact of pressure is less substantial than temperature, provided that the pressure is sufficient to maintain a liquid water phase. The second aspect pertains to the substratespecific dependence of sub- and supercritical water processes making their development and optimization highly dependent on the feedstock used. As a result, there is an urgent need to comprehensively understand the underlying fundamentals required to design reactors suitable for processing a wide range of feeds, rather than single-feed reactors. The last aspect concerns the minimum throughput of feedstock needed to ensure a sustained supply-chain relationship in the overall network configuration and logistics which becomes relevant when attempting to scale up subcritical/supercritical biomass processing schemes.

\section{Acknowledgements}

The authors would like to acknowledge the financial support by São Paulo Research Foundation - FAPESP (2011/19817-1 and 2013/04304-4) and CNPq (Process 303568/2016-0). MTT and ABB would like to thank the U.S. National Science Foundation (grant numbers 1342320 and 1554283).

\section{References}

[1] Acelas, N.Y., López, D.P., Brilman, D.W.F., Kersten, S.R.A., Kootstra, A.M.J., 2014. Supercritical water gasification of sewage sludge: gas production and phosphorus recovery. Bioresour. Technol. $174,167-175$

[2] Adil, İ.H., Yener, M.E., Bayındırlı, A., 2008. Extraction of total phenolics of sour cherry pomace by high pressure solvent anc subcritical fluid and determination of the antioxidant activities of the extracts. Sep. Sci. Technol. 43(5), 1091-1110.

[3] Agudelo, R.A., García-Aparicio, M.P., Görgens, J.F., 2016. Steam explosion pretreatment of triticale ( $\times$ Triticosecale Wittmack) straw for sugar production. New Biotechnol. 33(1), 153-163.

[4] Aliakbarian, B., Fathi, A., Perego, P., Dehghani, F., 2012. Extraction of antioxidants from winery wastes using subcritical water. J. Supercrit. Fluids. 65, 18-24.

[5] Amuzu-Sefordzi, B., Huang, J., Gong, M., 2014. Hydrogen production by supercritical water gasification of food waste using nickel and alkali catalysts. WIT Trans. Ecol. Environ. 190, 285-296.

[6] Azadi, P., Farnood, R., 2011. Review of heterogeneous catalysts for sub-and supercritical water gasification of biomass and wastes. Int. J. Hydrogen Energy. 36(16), 9529-9541

[7] Baccile, N., Laurent, G., Babonneau, F., Fayon, F., Titirici, M.M. Antonietti, M., 2009. Structural characterization of hydrothermal 
carbon spheres by advanced solid-state MAS 13C NMR investigations. J. Phys. Chem. C. 113(22), 9644-9654.

[8] Banerjee, P.N., Pranovich, A., Dax, D., Willför, S., 2014. Non-cellulosic heteropolysaccharides from sugarcane bagasse - sequential extraction with pressurized hot water and alkaline peroxide at different temperatures. Bioresour. Technol. 155, 446-450.

[9] Barati, M., Babatabar, M., Tavasoli, A., Dalai, A.K., Das, U., 2014. Hydrogen production via supercritical water gasification of bagasse using unpromoted and zinc promoted $\mathrm{Ru} / \gamma-\mathrm{Al}_{2} \mathrm{O}_{3}$ nanocatalysts. Fuel Process. Technol. 123, 140-148.

[10] Basu, P., Mettanant, V., 2009. Biomass gasification in supercritical water--a review. Int. J. Chem. Reactor Eng. 7(1).

[11] Behnia, I., Yuan, Z., Charpentier, P., Xu, C.C., 2016. Production of methane and hydrogen via supercritical water gasification of renewable glucose at a relatively low temperature: effects of metal catalysts and supports. Fuel Process. Technol. 143, 27-34

[12] Berge, N.D., Ro, K.S., Mao, J., Flora, J.R.V., Chappell, M.A., Bae, S., 2011. Hydrothermal carbonization of municipal waste streams. Environ. Sci. Technol. 45(13), 5696-5703.

[13] Bridgwater, A.V., Meier, D., Radlein, D., 1999. An overview of fast pyrolysis of biomass. Org. Geochem. 30(12), 1479-1493.

[14] Brunner, G., 2009. Near critical and supercritical water. Part I. Hydrolytic and hydrothermal processes. J. Supercrit. Fluids. 47(3), 373-381.

[15] Busch, D., Kammann, C., Grünhage, L., Müller, C., 2012. Simple biotoxicity tests for evaluation of carbonaceous soil additives: establishment and reproducibility of four test procedures. J. Environ. Qual. 41(4), 1023-1032.

[16] Byrd, A.J., Pant, K.K., Gupta, R.B., 2008. Hydrogen production from glycerol by reforming in supercritical water over $\mathrm{Ru} / \mathrm{Al}_{2} \mathrm{O}_{3}$ catalyst. Fuel. 87(13-14), 2956-2960.

[17] Calzavara, Y., Joussot-Dubien, C., Boissonnet, G., Sarrade, S., 2005. Evaluation of biomass gasification in supercritical water process for hydrogen production. Energy Convers. Manage. 46(4), 615-631.

[18] Çam, M., Hış1l, Y., 2010. Pressurised water extraction of polyphenols from pomegranate peels. Food Chem. 123(3), 878-885.

[19] Cantero, D.A., Bermejo, M.D., Cocero, M.J., 2013. High glucose selectivity in pressurized water hydrolysis of cellulose using ultra-fast reactors. Bioresour. Technol. 135, 697-703.

[20] Cao, W., Cao, C., Guo, L., Jin, H., Dargusch, M., Bernhardt, D., Yao, X., 2016. Hydrogen production from supercritical water gasification of chicken manure. Int. J. Hydrogen Energy. 41(48), 22722-22731.

[21] Castello, D., Fiori, L., 2011. Supercritical water gasification of biomass: thermodynamic constraints. Bioresour. Technol. 102(16), 7574-7582.

[22] Cheigh, C.I., Chung, E.Y., Chung, M.S., 2012. Enhanced extraction of flavanones hesperidin and narirutin from Citrus unshiu peel using subcritical water. J. Food Eng. 110(3), 472-477.

[23] Cheng, H.M., Yang, Q.H., Liu, C., 2001. Hydrogen storage in carbon nanotubes. Carbon. 39(10), 1447-1454.

[24] Chienthavorn, O., Insuan, W., 2004. Superheated water extraction of lime peel: a comparison with conventional methods. Anal. Lett. 37(11), 23932409.

[25] Chuntanapum, A., Matsumura, Y., 2009. Formation of tarry material from 5-HMF in subcritical and supercritical water. Ind. Eng. Chem. Res. 48(22), 9837-9846.

[26] Clark, J., Pfaltzgraff, L., 2012. Industrial symbiosis using green chemistry. Proceedings of the 2012 Clean Technology Conference and Trade Show, Santa Clara. 282-283

[27] Davis, R., Tao, L., Scarlata, C., Tan, E.C.D., Ross, J., Lukas, J., Sexton, D., 2015. Process design and economics for the conversion of lignocellulosic biomass to hydrocarbons: dilute-acid and enzymatic. National Renew. Energy Laboratory (NREL).

[28] Demir-Cakan, R., Baccile, N., Antonietti, M., Titirici, M.M., 2009. Carboxylate-rich carbonaceous materials via one-step hydrothermal carbonization of glucose in the presence of acrylic acid. Chem. Mater. 21(3), 484-490.

[29] Demirbas, A., 2010. Hydrogen production from biomass via supercritical water gasification. Energy Sources Part A. 32(14), 1342-1354.

[30] Ehara, K., Saka, S., 2002. A comparative study on chemical conversion of cellulose between the batch-type and flow-type systems in supercritical water. Cellulose. 9(3-4), 301-311.
[31] Ehara, K., Saka, S., 2005. Decomposition behavior of cellulose in supercritical water, subcritical water, and their combined treatments. J. Wood Sci. 51(2), 148-153.

[32] Eibisch, N., Schroll, R., Fuß, R., Mikutta, R., Helfrich, M., Flessa, H., 2015. Pyrochars and hydrochars differently alter the sorption of the herbicide isoproturon in an agricultural soil. Chemosphere. 119, 155 162.

[33] Elif, D., Nezihe, A., 2016. Hydrogen production by supercritical water gasification of fruit pulp in the presence of $\mathrm{Ru} / \mathrm{C}$. Int. J. Hydrogen Energy. 41(19), 8073-8083.

[34] Elliott, D.C., Hart, T.R., Schmidt, A.J., Neuenschwander, G.G. Rotness, L.J., Olarte, M.V., Zacher, A.H., Albrecht, K.O., Hallen, R.T., Holladay, J.E., 2013. Process development for hydrothermal liquefaction of algae feedstocks in a continuous-flow reactor. Algal Res. 2(4), 445-454.

[35] Falco, C., Baccile, N., Titirici, M.M., 2011. Morphological and structural differences between glucose, cellulose and lignocellulosic biomass derived hydrothermal carbons. Green Chem. 13(11), 3273 3281

[36] Farobie, O., Matsumura, Y., 2015. Biodiesel production in supercritical methanol using a novel spiral reactor. Procedia Environ. Sci. 28, 204-213

[37] Ferrari, A.C., Meyer, J.C., Scardaci, V., Casiraghi, C., Lazzeri, M., Mauri, F., Piscanec, S., Jiang, D., Novoselov, K.S., Roth, S., 2006 Raman spectrum of graphene and graphene layers. Phys. Rev. Lett. 97(18), 187401.

[38] Funke, A., Reebs, F., Kruse, A., 2013. Experimental comparison of hydrothermal and vapothermal carbonization. Fuel Process. Technol. $115,261-269$

[39] Funke, A., Ziegler, F., 2010. Hydrothermal carbonization of biomass: a summary and discussion of chemical mechanisms for process engineering. Biofuels, Bioprod. Biorefin. 4(2), 160-177.

[40] Gao, Y., Wang, X.H., Yang, H.P., Chen, H.P., 2012. Characterization of products from hydrothermal treatments of cellulose. Energy. 42(1) 457-465.

[41] Gong, M., Nanda, S., Romero, M.J., Zhu, W., Kozinski, J.A., 2017. Subcritical and supercritical water gasification of humic acid as a model compound of humic substances in sewage sludge. J. Supercrit. Fluids. 119, 130-138.

[42] Graf, D., Molitor, F., Ensslin, K., Stampfer, C., Jungen, A., Hierold, C., Wirtz, L., 2007. Spatially resolved Raman spectroscopy of singleand few-layer graphene. Nano Lett. 7(2), 238-242.

[43] Guan, Q., Huang, X., Liu, J., Gu, J., Miao, R., Chen, Q., Ning, P., 2016. Supercritical water gasification of phenol using a $\mathrm{Ru} / \mathrm{CeO}_{2}$ catalyst. Chem. Eng. J. 283, 358-365.

[44] Guo, S., Guo, L., Cao, C., Yin, J., Lu, Y., Zhang, X., 2012. Hydrogen production from glycerol by supercritical water gasification in a continuous flow tubular reactor. Int. J. Hydrogen Energy. 37(7) $5559-5568$

[45] Guo, Y., Wang, S.Z., Xu, D.H., Gong, Y.M., Ma, H.H., Tang, X.Y. 2010. Review of catalytic supercritical water gasification for hydrogen production from biomass. Renew. Sust. Energy Rev. 14(1), 334-343

[46] Guo, Z., Faghri, A., 2007. Vapor feed direct methanol fuel cells with passive thermal-fluids management system. J. Power Sources. 167(2), 378-390

[47] Hao, X., Guo, L., Zhang, X., Guan, Y., 2005. Hydrogen production from catalytic gasification of cellulose in supercritical water. Chem. Eng. J. 110(1-3), 57-65.

[48] Hao, X.H., Guo, L.J., Mao, X., Zhang, X.M., Chen, X.J., 2003. Hydrogen production from glucose used as a model compound of biomass gasified in supercritical water. Int. J. Hydrogen Energy. 28(1), 55-64

[49] Hassas-Roudsari, M., Chang, P.R., Pegg, R.B., Tyler, R.T., 2009. Antioxidant capacity of bioactives extracted from canola meal by subcritical water, ethanolic and hot water extraction. Food Chem. 114(2), 717-726

[50] He, L., Zhang, X., Xu, H., Xu, C., Yuan, F., Knez, Ž., Novak, Z., Gao, Y., 2012. Subcritical water extraction of phenolic compounds from pomegranate (Punica granatum L.) seed residues and investigation 
into their antioxidant activities with HPLC-ABTS+ assay. Food Bioprod. Process. 90(2), 215-223.

[51] Heilmann, S.M., Davis, H.T., Jader, L.R., Lefebvre, P.A., Sadowsky, M.J., Schendel, F.J., Von Keitz, M.G., Valentas, K.J., 2010. Hydrothermal carbonization of microalgae. Biomass Bioenergy. 34(6), 875-882.

[52] Hendriks, A.T.W.M., Zeeman, G., 2009. Pretreatments to enhance the digestibility of lignocellulosic biomass. Bioresour. Technol. 100(1), 1018.

[53] Huang, J., Lian, X., Wang, L., Zhu, C., Jin, H., Wang, R., 2017. Hydrogen production from glucose by supercritical water gasification with $\mathrm{Ni} / \mathrm{Zr}(\mathrm{Ce}, \mathrm{Y}) \mathrm{O}_{2-\delta}$ catalysts. Int. J. Hydrogen Energy. 42(7), 4613-4625.

[54] Jayapal, N., Samanta, A.K., Kolte, A.P., Senani, S., Sridhar, M., Suresh, K.P., Sampath, K.T., 2013. Value addition to sugarcane bagasse: Xylan extraction and its process optimization for xylooligosaccharides production. Ind. Crops Prod. 42, 14-24.

[55] Jazrawi, C., Biller, P., Ross, A.B., Montoya, A., Maschmeyer, T., Haynes, B.S., 2013. Pilot plant testing of continuous hydrothermal liquefaction of microalgae. Algal Res. 2(3), 268-277.

[56] Jiang, L., Zheng, A., Zhao, Z., He, F., Li, H., Wu, N., 2016. The comparison of obtaining fermentable sugars from cellulose by enzymatic hydrolysis and fast pyrolysis. Bioresour. Technol. 200, 8-13.

[57] Kanetake, T., Sasaki, M., Goto, M., 2007. Decomposition of a lignin model compound under hydrothermal conditions. Chem. Eng. Technol. 30(8), 1113-1122.

[58] Kang, K., Azargohar, R., Dalai, A.K., Wang, H., 2016a. Hydrogen production from lignin, cellulose and waste biomass via supercritical water gasification: catalyst activity and process optimization study. Energy Convers. Manage. 117, 528-537.

[59] Kang, K., Azargohar, R., Dalai, A.K., Wang, H., 2016b. Systematic screening and modification of Ni based catalysts for hydrogen generation from supercritical water gasification of lignin. Chem. Eng. J. 283, 10191032

[60] Kang, K., Shakouri, M., Azargohar, R., Dalai, A.K., Wang, H., $2016 \mathrm{c}$. Application of NI-CO/MG-AL catalyst system for hydrogen production via supercritical water gasification of lignocellulosic biomass. Catal. Lett. 146(12), 2596-2605.

[61] Kang, S., Li, X., Fan, J., Chang, J., 2012. Characterization of hydrochars produced by hydrothermal carbonization of lignin, cellulose, D-xylose, and wood meal. Ind. Eng. Chem. Res. 51(26), 9023-9031.

[62] Kanmaz, E.Ö., 2014. Subcritical water extraction of phenolic compounds from flaxseed meal sticks using accelerated solvent extractor (ASE). Eur. Food Res. Technol. 238(1), 85-91.

[63] Kapoor, M., Soam, S., Agrawal, R., Gupta, R.P., Tuli, D.K., Kumar, R., 2017. Pilot scale dilute acid pretreatment of rice straw and fermentable sugar recovery at high solid loadings. Bioresour. Technol. 224, 688-693.

[64] Karagöz, S., Bhaskar, T., Muto, A., Sakata, Y., Oshiki, T., Kishimoto, T., 2005. Low-temperature catalytic hydrothermal treatment of wood biomass: analysis of liquid products. Chem. Eng. J. 108(1-2), 127-137.

[65] Karmakar, A., Karmakar, S., Mukherjee, S., 2010. Properties of various plants and animals feedstocks for biodiesel production. Bioresour. Technol. 101(19), 7201-7210.

[66] Kim, Y., Kreke, T., Mosier, N.S., Ladisch, M.R., 2014. Severity factor coefficients for subcritical liquid hot water pretreatment of hardwood chips. Biotechnol. Bioeng. 111(2), 254-263.

[67] Kim, T., Assary, R.S., Curtiss, L.A., Marshall, C.L., Stair, P.C., 2011. Vibrational properties of levulinic acid and furan derivatives: Raman spectroscopy and theoretical calculations. J. Raman Spectrosc. 42(12), 2069-2076.

[68] Ko, M.J., Cheigh, C.I., Cho, S.W., Chung, M.S., 2011. Subcritical water extraction of flavonol quercetin from onion skin. J. Food Eng. 102(4), $327-333$

[69] Kulkarni, A., Suzuki, S., Etoh, H., 2008. Antioxidant compounds from Eucalyptus grandis biomass by subcritical liquid water extraction. J. Wood Sci. 54(2), 153-157.

[70] Lachos-Perez, D., Martinez-Jimenez, F., Rezende, C.A., Tompsett, G., Timko, M., Forster-Carneiro, T., 2016. Subcritical water hydrolysis of sugarcane bagasse: an approach on solid residues characterization. J. Supercrit. Fluids. 108, 69-78.
[71] Lachos-Perez, D., Prado, J.M., Torres-Mayanga, P., Forster-Carneiro, T., Meireles, M.A.A., 2015. Supercritical water gasification of biomass for hydrogen production: variable of the process. Food Public Health. 5(3), 92-101.

[72] Latham, K.G., Jambu, G., Joseph, S.D., Donne, S.W., 2014. Nitrogen doping of hydrochars produced hydrothermal treatment of sucrose in $\mathrm{H}_{2} \mathrm{O}, \mathrm{H}_{2} \mathrm{SO}_{4}$, and $\mathrm{NaOH}$. ACS Sustainable Chem. Eng. 2(4), 755-764.

[73] Latham, K.G., Simone, M.I., Dose, W.M., Allen, J.A., Donne, S.W. 2017. Synchrotron based NEXAFS study on nitrogen doped hydrothermal carbon: insights into surface functionalities and formation mechanisms. Carbon. 114, 566-578.

[74] Lee, I.G., Kim, M.S., Ihm, S.K., 2002. Gasification of glucose in supercritical water. Ind. Eng. Chem. Res. 41(5), 1182-1188.

[75] Lee, K.A., Kim, K.T., Kim, H.J., Chung, M.S., Chang, P.S., Park, H. Pai, H.D., 2014. Antioxidant activities of onion (Allium cepa L.) peel extracts produced by ethanol, hot water, and subcritical water extraction. Food Sci. Biotechnol. 23(2), 615-621.

[76] Li, F., Liu, L., An, Y., He, W., Themelis, N.J., Li, G., $2016 a$. Hydrothermal liquefaction of three kinds of starches into reducing sugars. J. Cleaner Prod. 112, 1049-1054.

[77] Li, K., Wan, J., Wang, X., Wang, J., Zhang, J., 2016b. Comparison of dilute acid and alkali pretreatments in production of fermentable sugars from bamboo: effect of tween 80. Ind. Crops Prod. 83, 414 422.

[78] Li, M., Li, W., Liu, S., 2011. Hydrothermal synthesis, characterization, and $\mathrm{KOH}$ activation of carbon spheres from glucose. Carbohydr. Res. 346(8), 999-1004.

[79] Liang, J., Chen, X., Wang, L., Wei, X., Qiu, F., Lu, C., 2016. Hydrolysis behaviors of sugarcane bagasse pith in subcritical carbon dioxide-water. RSC Adv. 6(101), 99322-99330.

[80] Liao, B., Guo, L., Lu, Y., Zhang, X., 2013. Solar receiver/reactor for hydrogen production with biomass gasification in supercritical water. Int. J. Hydrogen Energy. 38(29), 13038-13044.

[81] Libra, J.A., Ro, K.S., Kammann, C., Funke, A., Berge, N.D., Neubauer, Y., Titirici, M.M., Fühner, C., Bens, O., Kern, J., Emmerich K.H., 2011. Hydrothermal carbonization of biomass residuals: a comparative review of the chemistry, processes and applications of wet and dry pyrolysis. Biofuels. 2(1), 71-106.

[82] Lin, R., Cheng, J., Ding, L., Song, W., Qi, F., Zhou, J., Cen, K., 2015. Subcritical water hydrolysis of rice straw for reducing sugar production with focus on degradation by-products and kinetic analysis. Bioresour. Technol. 186, 8-14.

[83] Liu, Z., Quek, A., Hoekman, S.K., Balasubramanian, R., 2013. Production of solid biochar fuel from waste biomass by hydrothermal carbonization. Fuel. 103, 943-949.

[84] Liu, Z., Zhang, F.S., Wu, J., 2010. Characterization and application of chars produced from pinewood pyrolysis and hydrotherma treatment. Fuel. 89(2), 510-514.

[85] Louw, J., Schwarz, C.E., Burger, A.J., 2016. Supercritical water gasification of Eucalyptus grandis and related pyrolysis char: effect of feedstock composition. Bioresour. Technol. 216, 1030-1039.

[86] Lu, Y., Guo, L., Zhang, X., Ji, C., 2012. Hydrogen production by supercritical water gasification of biomass: explore the way to maximum hydrogen yield and high carbon gasification efficiency. Int. J. Hydrogen Energy. 37(4), 3177-3185.

[87] Lu, Y., Li, S., Guo, L., Zhang, X., 2010. Hydrogen production by biomass gasification in supercritical water over $\mathrm{Ni} / \gamma \mathrm{Al}_{2} \mathrm{O}_{3}$ and $\mathrm{Ni} / \mathrm{CeO} 2-\gamma \mathrm{Al}_{2} \mathrm{O}_{3}$ catalysts. Int. J. Hydrogen Energy. 35(13), 71617168.

[88] Lu, Y., Guo, L., Zhang, X., Yan, Q., 2007. Thermodynamic modeling and analysis of biomass gasification for hydrogen production in supercritical water. Chem. Eng. J. 131(1-3), 233-244

[89] Lu, Y.J., Guo, L.J., Ji, C.M., Zhang, X.M., Hao, X.H., Yan, Q.H., 2006. Hydrogen production by biomass gasification in supercritical water: a parametric study. Int. J. Hydrogen Energy. 31(7), 822-831.

[90] Machado, A.P.D.F., Pasquel-Reátegui, J.L., Barbero, G.F., Martínez, J., 2015. Pressurized liquid extraction of bioactive compounds from blackberry (Rubus fruticosus L.) residues: a comparison with conventional methods. Food Res. Int. 77, 675-683. 
[91] Madenoğlu, T.G., Sağlam, M., Yüksel, M., Ballice, L., 2016. Hydrothermal gasification of biomass model compounds (cellulose and lignin alkali) and model mixtures. J. Supercrit. Fluids. 115, 79-85.

[92] Madenoğlu, T.G., Kurt, S., Sağlam, M., Yüksel, M., Gökkaya, D., Ballice, L., 2012. Hydrogen production from some agricultural residues by catalytic subcritical and supercritical water gasification. J. Supercrit. Fluids. 67, 22-28

[93] Malghani, S., Gleixner, G., Trumbore, S.E., 2013. Chars produced by slow pyrolysis and hydrothermal carbonization vary in carbon sequestration potential and greenhouse gases emissions. Soil Biol. Biochem. 62, 137-146.

[94] Marrone, P.A., Hong, G.T., 2009. Corrosion control methods in supercritical water oxidation and gasification processes. J. Supercrit. Fluids. 51(2), 83-103.

[95] Miyazawa, T., Funazukuri, T., 2005. Polysaccharide hydrolysis accelerated by adding carbon dioxide under hydrothermal conditions. Biotechnol. Progr. 21(6), 1782-1785

[96] Mohan, M., Banerjee, T., Goud, V.V., 2015. Hydrolysis of bamboo biomass by subcritical water treatment. Bioresour. Technol. 191, 244252.

[97] Molino, A., Migliori, M., Macrì, D., Valerio, V., Villone, A., Nanna, F., Iovane, P., Marino, T., 2016. Glucose gasification in super-critical water conditions for both syngas production and green chemicals with a continuous process. Renew. Energy. 91, 451-455.

[98] Muangrat, R., Onwudili, J.A., Williams, P.T., 2010. Influence of $\mathrm{NaOH}$, $\mathrm{Ni} / \mathrm{Al}{ }_{2} \mathrm{O}_{3}$ and $\mathrm{Ni} / \mathrm{SiO}_{2}$ catalysts on hydrogen production from the subcritical water gasification of model food waste compounds. Appl. Catal., B. 100(1-2), 143-156

[99] Mumme, J., Eckervogt, L., Pielert, J., Diakité, M., Rupp, F., Kern, J., 2011. Hydrothermal carbonization of anaerobically digested maize silage. Bioresour. Technol. 102(19), 9255-9260.

[100]Nanda, S., Dalai, A.K., Kozinski, J.A., 2016a. Supercritical water gasification of timothy grass as an energy crop in the presence of alkali carbonate and hydroxide catalysts. Biomass Bioenergy. 95, 378-387.

[101]Nanda, S., Reddy, S.N., Dalai, A.K., Kozinski, J.A., 2016b. Subcritical and supercritical water gasification of lignocellulosic biomass impregnated with nickel nanocatalyst for hydrogen production. Int. J. Hydrogen Energy. 41(9), 4907-4921

[102] Nanda, S., Reddy, S.N., Hunter, H.N., Dalai, A.K., Kozinski, J.A., 2015. Supercritical water gasification of fructose as a model compound for waste fruits and vegetables. J. Supercrit. Fluids. 104, 112-121.

[103] Narita, Y., Inouye, K. 2012. High antioxidant activity of coffee silverskin extracts obtained by the treatment of coffee silverskin with subcritical water. Food Chem. 135(3), 943-949.

[104]Olanrewaju, K.B., 2012. Reaction kinetics of cellulose hydrolysis in subcritical and supercritical water. Doctoral dissertation. Repositorio da Universidade Nova.

[105] Ondze, F., Boutin, O., Ruiz, J.C., Ferrasse, J.H., Charton, F., 2015. Supercritical water gasification of beet residues: from batch to continuous reactor. Chem. Eng. Sci. 123, 350-358

[106] Onwudili, J.A. Williams, P.T., 2013. Enhanced methane and hydrogen yields from catalytic supercritical water gasification of pine wood sawdust via pre-processing in subcritical water. RSC Adv. 3(30), 1243212442.

[107]Parthasarathy, P., Narayanan, K.S., 2014. Hydrogen production from steam gasification of biomass: influence of process parameters on hydrogen yield-a review. Renewable Energy. 66, 570-579.

[108]Pedras, B.M.d.S., 2015. Valorization of grape pomace through hot compressed water extraction/hydrolysis. Doctoral dissertation.

[109]Peterson, A.A., Vogel, F., Lachance, R.P., Fröling, M., Antal Jr, M.J., Tester, J.W., 2008. Thermochemical biofuel production in hydrothermal media: a review of sub-and supercritical water technologies. Energy Environ. Sci. 1(1), 32-65.

[110] Pińkowska, H., Wolak, P., Złocińska, A., 2012. Hydrothermal decomposition of alkali lignin in sub-and supercritical water. Chem. Eng, J. $187,410-414$

[111] Pińkowska, H., Wolak, P., Złocińska, A., 2011. Hydrothermal decomposition of xylan as a model substance for plant biomass wasteHydrothermolysis in subcritical water. Biomass Bioenergy. 35(9), 39023912.
[112]Pourali, O., Asghari, F.S., Yoshida, H., 2010. Production of phenolic compounds from rice bran biomass under subcritical water conditions. Chem. Eng. J. 160(1), 259-266.

[113]Prado, J.M., Forster-Carneiro, T., Rostagno, M.A., FollegattiRomero, L.A., Maugeri Filho, F.M., Meireles, M.A.A., 2014 Obtaining sugars from coconut husk, defatted grape seed, and pressed palm fiber by hydrolysis with subcritical water. J. Supercrit. Fluids 89, 89-98.

[114]Prado, J.M., Lachos-Perez, D., Forster-Carneiro, T., Rostagno, M.A. 2016. Sub- and supercritical water hydrolysis of agricultural and fooc industry residues for the production of fermentable sugars: a review. Food Bioprod. Process. 98, 95-123.

[115]Prado, J.M., Vardanega, R., Nogueira, G.C., Forster-Carneiro, T., Rostagno, M.A., Filho, F.M., Meireles, M.A.A., 2017. Valorization of residual biomasses from agri-food industry by subcritical water hydrolysis assisted by $\mathrm{CO}_{2}$. Energy Fuels. 31(3), 2838-2846.

[116] Qin, L., Li, X., Zhu, J.Q., Li, W.C., Xu, H., Guan, Q.M., Zhang, M.T., Li, B.Z., Yuan, Y.J., 2017. Optimization of ethylenediamine pretreatment and enzymatic hydrolysis to produce fermentable sugars from corn stover. Ind. Crops Prod. 102, 51-57.

[117]Reddy, S.N., Nanda, S., Dalai, A.K., Kozinski, J.A., 2014 Supercritical water gasification of biomass for hydrogen production. Int. J. Hydrogen Energy. 39(13), 6912-6926.

[118]Regmi, P., Moscoso, J.L.G., Kumar, S., Cao, X., Mao, J., Schafran, G., 2012. Removal of copper and cadmium from aqueous solution using switchgrass biochar produced via hydrothermal carbonization process. J. Environ. Manage. 109, 61-69.

[119]Ro, K.S., Novak, J.M., Johnson, M.G., Szogi, A.A., Libra, J.A. Spokas, K.A., Bae, S., 2016. Leachate water quality of soils amended with different swine manure-based amendments. Chemosphere. 142 92-99.

[120]Rogalinski, T., Ingram, T., Brunner, G., 2008. Hydrolysis of lignocellulosic biomass in water under elevated temperatures and pressures. J. Supercrit. Fluids. 47(1), 54-63.

[121] Romero-García, J.M., Lama-Muñoz, A., Rodríguez-Gutiérrez, G., Moya, M., Ruiz, E., Fernández-Bolaños, J., Castro, E., 2016. Obtaining sugars and natural antioxidants from olive leaves by steam-explosion. Food Chem. 210, 457-465.

[122]Rostagno, M.A., Prado, J.M., 2013. Natural product extraction: principles and applications. Royal Society of Chemistry.

[123]Rostagno, M.A., Prado, J.M., Mudhoo, A., Santos, D.T., ForsterCarneiro, T., Meireles, M.A., 2015. Subcritical and supercritical technology for the production of second generation bioethanol. Crit. Rev. Biotechnol. 35(3), 302-312.

[124] Sadezky, A., Muckenhuber, H., Grothe, H., Niessner, R., Pöschl, U., 2005. Raman microspectroscopy of soot and related carbonaceous materials: spectral analysis and structural information. Carbon. 43(8), $1731-1742$

[125]Safari, F., Salimi, M., Tavasoli, A., Ataei, A., 2016. Non-catalytic conversion of wheat straw, walnut shell and almond shell into hydrogen rich gas in supercritical water media. Chin. J. Chem. Eng. 24(8), 1097-1103.

[126] Sakaki, T., Shibata, M., Sumi, T., Yasuda, S., 2002. Saccharification of cellulose using a hot-compressed water-flow reactor. Ind. Eng. Chem. Res. 41(4), 661-665.

[127] Sasaki, M., Adschiri, T., Arai, K., 2004. Kinetics of cellulose conversion at $25 \mathrm{MPa}$ in sub-and supercritical water. AIChE J. 50(1), 192-202.

[128] Sasaki, M., Fang, Z., Fukushima, Y., Adschiri, T., Arai, K., 2000. Dissolution and hydrolysis of cellulose in subcritical and supercritical water. Ind. Eng. Chem. Res. 39(8), 2883-2890.

[129] Sato, T., Furusawa, T., Ishiyama, Y., Sugito, H., Miura, Y., Sato, M. Suzuki, N., Itoh, N., 2006. Effect of water density on the gasification of lignin with magnesium oxide supported nickel catalysts in supercritical water. Ind. Eng. Chem. Res. 45(2), 615-622.

[130] Sawai, O., Nunoura, T., Yamamoto, K., 2014. Supercritical water gasification of sewage sludge using bench-scale batch reactor: advantages and drawbacks. J. Mater. Cycles Waste Manage. 16(1) $82-92$. 
[131] Schacht, C., Zetzl, C., Brunner, G., 2008. From plant materials to ethanol by means of supercritical fluid technology. J. Supercrit. Fluids. 46(3), 299-321.

[132] Seif, S., Fatemi, S., Tavakoli, O., Bahmanyar, H., 2016. Hydrogen production through hydrothermal gasification of industrial wastewaters using transition metal oxide catalysts. J. Supercrit. Fluids. 114, 32-45.

[133] Sevilla, M., Fuertes, A.B., 2009a. Chemical and structural properties of carbonaceous products obtained by hydrothermal carbonization of saccharides. Chem. Eur. J. 15(16), 4195-4203.

[134] Sevilla, M., Fuertes, A.B., 2009b. The production of carbon materials by hydrothermal carbonization of cellulose. Carbon. 47(9), 2281-2289.

[135] Sevilla, M., Fuertes, A.B., Mokaya, R., 2011. High density hydrogen storage in superactivated carbons from hydrothermally carbonized renewable organic materials. Energy Environ. Sci. 4(4), 1400-1410.

[136] Shimanouchi, T., Ueno, S., Yang, W., Kimura, Y., 2014. Extraction of reducing sugar with anti-oxidative scavengers from peels of Carya cathayensis Sarg.: use of subcritical water. Environ. Eng. Res. 19(1), 4145.

[137] Shitu, A., Izhar, S., Tahir, T.M., 2015. Sub-critical water as a green solvent for production of valuable materials from agricultural waste biomass: a review of recent work. Global J. Environ. Sci. Manage. 1(3), 255-264.

[138]Singh, P.P., Saldaña, M.D.A., 2011. Subcritical water extraction of phenolic compounds from potato peel. Food Res. Int. 44(8), 2452-2458.

[139] Sivasangar, S., Zainal, Z., Salmiaton, A., Taufiq-Yap, Y.H., 2015. Supercritical water gasification of empty fruit bunches from oil palm for hydrogen production. Fuel. 143, 563-569.

[140] Smith, M.W., Dallmeyer, I., Johnson, T.J., Brauer, C.S., McEwen, J.S., Espinal, J.F., Garcia-Perez, M., 2016. Structural analysis of char by Raman spectroscopy: improving band assignments through computational calculations from first principles. Carbon. 100, 678-692.

[141] Sohi, S., Krull, E., Lopez-Capel, E., Bol, R., 2010. A review of biochar and its use and function in soil. Adv. Agron. 105(1), 47-82.

[142] Srinivas, K., King, J.W., Howard, L.R., Monrad, J.K., 2010. Solubility of gallic acid, catechin, and protocatechuic acid in subcritical water from (298.75 to 415.85) K. J. Chem. Eng. Data. 55(9), 3101-3108.

[143] Susanti, R.F., Dianningrum, L.W., Yum, T., Kim, Y., Lee, B.G., Kim, J., 2012. High-yield hydrogen production from glucose by supercritical water gasification without added catalyst. Int. J. Hydrogen Energy. 37(16), 11677-11690.

[144]Timko, M.T., Marre, S., Maag, A.R., 2016a. Formation and characterization of emulsions consisting of dense carbon dioxide and water: ultrasound. J. Supercrit. Fluids. 109, 51-60.

[145]Timko, M.T., Maag, A.R., Venegas, J.M., McKeogh, B., Yang, Z., Tompsett, G.A., Escapa, S., Toto, J., Heckley, E., Greenaway, F.T., 2016b. Spectroscopic tracking of mechanochemical reactivity and modification of a hydrothermal char. RSC Adv. 6(15), 12021-12031.

[146] Titirici, M.M., Antonietti, M., 2010. Chemistry and materials options of sustainable carbon materials made by hydrothermal carbonization. Chem. Soc. Rev. 39(1), 103-116.

[147] Titirici, M.M., Antonietti, M., 2010. Chemistry and materials options of sustainable carbon materials made by hydrothermal carbonization. Chem. Soc. Rev. 39(1), 103-116.

[148] Titirici, M.M., Antonietti, M., Baccile, N., 2008. Hydrothermal carbon from biomass: a comparison of the local structure from poly-to monosaccharides and pentoses/hexoses. Green Chem. 10(11), 12041212 .

[149] Titirici, M.M., Thomas, A., Yu, S.H., Müller, J.O., Antonietti, M., 2007. A direct synthesis of mesoporous carbons with bicontinuous pore morphology from crude plant material by hydrothermal carbonization. Chem. Mater. 19(17), 4205-4212.

[150] Vardanega, R., Prado, J.M., Meireles, M.A.A., 2015. Adding value to agri-food residues by means of supercritical technology. J. Supercrit. Fluids. 96, 217-227.

[151] Vergara-Salinas, J.R., Bulnes, P., Zúñiga, M.C., Pérez-Jiménez, J., Torres, J.L., Mateos-Martín, M.L., Agosin, E., Pérez-Correa, J.R., 2013. Effect of pressurized hot water extraction on antioxidants from grape pomace before and after enological fermentation. J. Agric. Food Chem. 61(28), 6929-6936.
[152]Wang, X., Chen, Q., Lü, X., 2014. Pectin extracted from apple pomace and citrus peel by subcritical water. Food Hydrocolloids. 38 129-137.

[153]Wei, L., Sevilla, M., Fuertes, A.B., Mokaya, R., Yushin, G., 2011. Hydrothermal carbonization of abundant renewable natural organic chemicals for high-performance supercapacitor electrodes. Adv. Energy Mater. 1(3), 356-361.

[154]Wiedner, K., Naisse, C., Rumpel, C., Pozzi, A., Wieczorek, P. Glaser, B., 2013. Chemical modification of biomass residues during hydrothermal carbonization-What makes the difference, temperature or feedstock?. Org. Geochem. 54, 91-100.

[155] Williams, P.T., Onwudili, J., 2005. Composition of products from the supercritical water gasification of glucose: a model biomass compound. Ind. Eng. Chem. Res. 44(23), 8739-8749.

[156]Xu, H., Wang, W., Liu, X., Yuan, F., Gao, Y., 2015. Antioxidative phenolics obtained from spent coffee grounds (Coffea arabica L.) by subcritical water extraction. Ind. Crops Prod. 76, 946-954.

[157]Xue, Y., Gao, B., Yao, Y., Inyang, M., Zhang, M., Zimmerman, A.R. Ro, K.S., 2012. Hydrogen peroxide modification enhances the ability of biochar (hydrochar) produced from hydrothermal carbonization of peanut hull to remove aqueous heavy metals: batch and column tests. Chem. Eng. J. 200-202, 673-680.

[158] Yamaguchi, A., Hiyoshi, N., Sato, O., Bando, K.K., Osada, M., Shirai, M., 2009. Hydrogen production from woody biomass over supported metal catalysts in supercritical water. Catal. Today. 146(12), 192-195.

[159] Yamamoto, M., Iakovlev, M., Bankar, S., Tunc, M.S., van Heiningen A., 2014. Enzymatic hydrolysis of hardwood and softwood harvest residue fibers released by sulfur dioxide-ethanol-water fractionation. Bioresour. Technol. 167, 530-538

[160] Yang, Y., Cui, J., Zheng, M., Hu, C., Tan, S., Xiao, Y., Yang, Q., Liu, Y., 2012. One-step synthesis of amino-functionalized fluorescent carbon nanoparticles by hydrothermal carbonization of chitosan. Chem. Commun. 48(3), 380-382.

[161] Yong, T.L.K., Yukihiko, M., 2013. Kinetic analysis of guaiaco. conversion in sub-and supercritical water. Ind. Eng. Chem. Res. 52(26), 9048-9059.

[162] Yong, T.L.K., Matsumura, Y. 2012. Reaction kinetics of the lignin conversion in supercritical water. Ind. Eng. Chem. Res. 51(37), 11975-11988.

[163] Yoon, S.H., Lim, S., Song, Y., Ota, Y., Qiao, W., Tanaka, A., Mochida, I., 2004. KOH activation of carbon nanofibers. Carbon. 42(8-9), 1723-1729.

[164] Yoshida, H., Izhar, S., Nishio, E., Utsumi, Y., Kakimori, N., Asghari, F.S., 2015. Recovery of indium from TFT and CF glasses of LCD wastes using $\mathrm{NaOH}$-enhanced sub-critical water. J. Supercrit. Fluids. 104, 40-48

[165] Yoshida, H., Tokumoto, H., Ishii, K., Ishii, R., 2009. Efficient, high speed methane fermentation for sewage sludge using subcritical water hydrolysis as pretreatment. Bioresour. Technol. 100(12), 2933-2939.

[166] Yoshida, T., Oshima, Y., Matsumura, Y., 2004. Gasification of biomass model compounds and real biomass in supercritical water. Biomass Bioenergy. 26(1), 71-78.

[167]Youssef, E.A., Nakhla, G., Charpentier, P.A., 2011. Oleic acic gasification over supported metal catalysts in supercritical water: hydrogen production and product distribution. Int. J. Hydrogen Energy. 36(8), 4830-4842.

[168] Yu, Y., Lou, X., Wu, H., 2008. Some recent advances in hydrolysis of biomass in hot-compressed water and its comparisons with other hydrolysis methods. Energy Fuels. 22(1), 46-60.

[169] Yusman, M., 2007. Hydrothermal gasification of organic waste. Proceedings of International Symposium on EcoTopia Science.

[170]Zeković, Z., Vidović, S., Vladić, J., Radosavljević, R., Cvejin, A., Elgndi, M.A., Pavlić, B., 2014. Optimization of subcritical water extraction of antioxidants from Coriandrum sativum seeds by response surface methodology. J. Supercrit. Fluids. 95, 560-566.

[171]Zhao, J., Wu, J., 2006. Preparation and characterization of the fluorescent chitosan nanoparticle probe. Chin. J. Anal. Chem. 34(11), 1555-1559 
[172]Zhao, Y., Chen, M., Zhao, Z., Yu, S., 2015. The antibiotic activity and mechanisms of sugarcane (Saccharum officinarum L.) bagasse extract against food-borne pathogens. Food Chem. 185, 112-118.

[173]Zhiyong, Y., Xiuyi, T., 2015. Hydrogen generation from oily wastewater via supercritical water gasification (SCWG).J.Ind. Eng. Chem. 23, 44-49.
[174]Zhu, Z., Liu, Z., Zhang, Y., Li, B., Lu, H., Duan, N., Si, B., Shen, R., Lu, J. 2016. Recovery of reducing sugars and volatile fatty acids from cornstalk at different hydrothermal treatment severity. Bioresour. Technol., 199, 220-227. 